\title{
Modelling the Effects of a Glyphosate Ban on Weed Management in Silage Maize Production
}

\author{
Journal Article \\ Author(s): \\ Böcker, Thomas; Britz, Wolfgang; Finger, Robert (D) \\ Publication date: \\ 2018-03 \\ Permanent link: \\ https://doi.org/10.3929/ethz-b-000223167
}

Rights / license:

Creative Commons Attribution-NonCommercial-NoDerivatives 4.0 International

Originally published in:

Ecological Economics 145, https://doi.org/10.1016/j.ecolecon.2017.08.027 


\section{Postprint}

This is the accepted version of a paper published in Ecological Economics.

\section{Citation for the original published paper:}

Böcker, T., Britz, W. and Finger, R. (2018). Modelling the Effects of a Glyphosate Ban on Weed Management in Silage Maize Production. Ecological Economics Vol. 145: 182193. https://doi.org/10.1016/j.ecolecon.2017.08.027

Access to the published version may require subscription.

N.B. When citing this work, cite the original published paper. 


\title{
Modelling the Effects of a Glyphosate Ban on Weed Management in Silage Maize Production
}

\author{
Thomas Böcker ${ }^{a}$, Wolfgang Britz ${ }^{a}$ and Robert Finger ${ }^{b}$ \\ a Institute for Food and Resource Economics, Rheinische Friedrich-Wilhelms- \\ Universität Bonn, Germany. Contact: t.boecker@ilr.uni-bonn.de \\ b Agricultural Economics and Policy Group, ETH Zürich, Switzerland.
}

\begin{abstract}
A bio-economic model is developed that allows a detailed representation of optimal weed control decisions. It implements an output damage control approach for German silage maize production, considering almost eighty mechanical and herbicide based weed control options against over thirty weeds, working with detailed data on weed abundance and yields for more than three hundred municipalities in the federal state of North-Rhine-Westphalia. We apply the model to simulate economic optimal weed control over two growing periods under current environmental standards and under the scenario of a glyphosate ban as recently discussed after glyphosate was classified as probably carcinogenic to humans. Considering different levels of weed pressure, we find that adjustments in the intensity of mechanical pre-sowing strategies are an optimal response to a glyphosate ban, causing yield reductions of about $1 \%$. In contrast, we find little evidence for a substitution towards selective herbicides postsowing. On average, the aggregated economic impacts of a glyphosate ban are small, i.e. at about $€ 1-2 /$ ha, but single farms may face higher losses at about $€ 10 /$ ha.
\end{abstract}

Keywords: Output damage control; pest management; herbicide; maize; glyphosate; Germany. 


\section{Introduction}

Reducing risks caused by pesticide application is a crucial component of current agrienvironmental policy debates in Europe. Different measures are proposed to control pesticide use and the connected risks for the environment and human health, resulting in more sustainable agricultural systems (Lefebvre et al., 2015). The proposed measures comprise banning specific pesticides (e.g. neonicotinoids and glyphosate; Gross, 2013; Schulte and Theuvsen, 2015) or introducing pesticide taxes (Böcker and Finger, 2016; Finger et al., 2017). Especially the renewed licensing or banning of the broad-spectrum herbicide glyphosate in the EU provoked heated discussions after the International Agency for Research on Cancer classified glyphosate as "probably carcinogenic to humans" (Guyton et al., 2015). Ex-ante information on health and environmental risks reduction and on the impacts on farmer's income is needed to inform the debate on policy measures targeting pesticides (Falconer, 1998). As substitution effects with other herbicides are likely if specific products are targeted, potential changes in farm management must be depicted in detail. In the debate on banning glyphosate, however, there is a large uncertainty about those effects (Schulte and Theuvsen, 2015; see also the position paper of Steinmann et al., 2016). In this paper, we develop a tool for such detailed impact assessment of environmental standards or other policy measures affecting specific pesticides and apply it to assess a potential ban of glyphosate.

In available assessments on pesticide application behaviour of farmers, mainly econometric and optimisation modelling approaches or combinations of both are applied (see Böcker and Finger, 2017). Econometric applications are usually based on historical data, for instance of pesticide applications, and are used to explain historical developments or to make recommendations on decision making. Optimisation and simulation models presume, for example, optimal decision making based on more or less detailed production function approaches combined with an economic objective such as profit maximisation. They can hence be used for what-if-analyses even if observations are missing (Grovermann et al., 2017). Existing approaches of the latter group are, however, not detailed enough to assess measures addressing individual 
pesticides, such as glyphosate in our application. For example, Guan et al. (2005) work with a monetary aggregate over fungicides, herbicides and other pesticides; but, higher total costs for pesticide applications do not necessarily lead to a better weed treatment and vice versa. Babcock et al. (1992) and Kuosmanen et al. (2006) use the total amount of active substances (AS) of fungicides respectively insecticides as an indicator for pesticide use in apple production respectively cotton, neglecting any differences in risk between different AS. Karagiannis and Tzouvelekas (2012) measure insecticide application in olive orchards based on litres of insecticides, and Jacquet et al. (2011) model five different alternatives (intensive, recommended by extension services, $2 \times$ integrated practices and organic farming practices), both ignoring the diversity of existing AS.

In this paper, we extend the literature studying policy effects on pest management by i) making use of the output damage function approach (e.g. Karagiannis and Tzouvelekas, 2012), and ii) differentiating in detail a larger set of pre-sowing and postsowing weed control options with regard to their yield impact. Specifically, we consider for each strategy both costs and efficacy of controlling individual weeds. Moreover, we develop a framework that is site-specific and allows investigating weed management over time and space. Our empirical analysis focusses on silage maize, one of the most relevant crops in Germany, where pest management mainly relies on herbicide application (Julius Kühn-Institut, 2016). We apply the model to the Federal State of North-Rhine-Westphalia (NRW), Germany, and account for the spatial heterogeneity of weed pressure and yield potential at municipality level. The model identifies economically optimal herbicide strategies in silage maize in each municipality at given pesticide and crop prices as well as specifications and regulations of pesticide use. We apply this model to study the impact of a ban of glyphosate on herbicide use and/or mechanical weed control measures and related costs compared to the current situation. At the moment, there are no alternative chemical herbicides approved to replace glyphosate for pre-sowing application (Kehlenbeck et al., 2015). Thus, mechanical weed control is the only alternative which removes all potential risks from herbicides before sowing. However, as claimed in some discussions on the topic, 
selective herbicides could potentially be used at higher rates after sowing, even increasing the overall health and environmental risks.

The remainder of this article is structured as follows: section 2 presents the damage control approach, the production function and its parameterisation. The data used in the model is depicted in section 3. The following section presents results, starting with some descriptive results before testing several hypotheses. Afterwards, both the model and the results are discussed and, finally, conclusions drawn.

\section{Methodology}

We develop a bio-economic weed control model for silage maize in $m$ regions, i.e. 377 silage maize producing municipalities in NRW. A two-year cropping period is considered where maize is grown in each of the two years $t$, a standard farming practise. The expected gross margin $E(\pi)$ in year $t$ for different pre- (index $b$ ) and postsowing (index $h$ ) weed control strategies is defined as:

$$
E\left(\pi_{m, t, b, h}\right)=\left[y_{m, t, b, h}^{*} \cdot E(P)-c(b)-c_{s}(b)-c(h)-c_{f}(y)-c_{o}\right],
$$

where $y_{m, t, b, h}^{*}$ is the expected yield, $E(P)$ is the expected price for maize, $c(b)$ and $c(h)$ are the pre- and post-sowing weed management (and tillage) costs for a certain strategy and $c_{s}(b)$ are variable costs for sowing depending on the pre-sowing strategy (the more expensive direct precision drill is needed for some types of conservation tillage). $c_{f}(y)$ are costs for fertiliser depending on the yield and $c_{o}$ are other costs (e.g. proportionate costs for rating and liming). Harvest costs are not included because maize is sold ex field such that the buyer performs the harvest, which is also reflected in lower output prices.

\subsection{The Damage Control Approach}

An output damage function is used to determine the expected yield $y^{*}$ (Fox and Weersink, 1995; Guan et al., 2006, 2005; Hall and Norgaard, 1973; Oude Lansink and Carpentier, 2001; Pannell, 1990; Talpaz and Borosh, 1974). It depicts first the effect of the damage control input(s) on the population of the damaging organism and from 
there the resulting yield reduction from surviving damaging organisms (Karagiannis and Tzouvelekas, 2012). We follow Guan et al. (2005) and distinct in the production function $y=G(x, D(h))$ between productive $(x)$ and damage-controlling inputs $(h)$ where $D(h)$ is the multiplicative damage controlling effect on the interval $[0,1] . h$ is, for example, the efficacy of a herbicide against a specific weed. If $D(h)$ is equal to unity, no losses due to pests, diseases or weeds occur. Besides chemical inputs, also mechanical inputs such as hoeing or ploughing can be considered as damagecontrolling, which somewhat challenges a clear distinction between $h$ and $x$. Different proposals regarding the functional form of $D(h)$ have been made (see e.g. CarrascoTauber and Moffitt, 1992; Fox and Weersink, 1995; Kuosmanen et al., 2006; Lichtenberg and Zilberman, 1986). We follow Guan et al. (2005) and use the exponential form because it is particularly suited to represent the underlying biological processes:

$$
\mathrm{D}(\mathrm{h})=1-\mathrm{e}^{-\left(\beta_{0}+\beta_{1} \cdot \mathrm{z}(\mathrm{h})\right)^{2}}, \quad \beta_{0}, \beta_{1} \geq 0 .
$$

This functional form implies decreasing marginal damage control in input use, a reasonable assumption as, e.g., additional efforts in weed control on an almost weed free field will not lead to much higher damage control. Parameters $\beta_{0}$ and $\beta_{1}$ quantify the effects of inputs on damage control; their estimation is explained in the next sections. The decision variable in our model is $z(h)$, the chosen level of damage control.

\subsection{Specification of the Damage Controlling Effect}

We consider the 32 most important weeds for the case study region in our analysis (see Table 1 in section 0). Each plant protection strategy is characterised by its weed specific damage control effect, i.e. a column vector $h$ with $j 1 \times 32$ entries ranging between 0 and 1, allowing to represent how specific herbicides and mechanical strategies differ in their impact on individual weeds. Often, an herbicide strategy comprises several herbicide products. The resulting control success is typically not additive since the comprised herbicides usually have a similar spectrum of action. More likely is the case that the maximum suppression effect of any herbicide is crucial 
for the success. Also, we add a multiplier $a_{i}$ to each weed $w_{m, i}$ to differentiate yield depression effects by weed, depicted by the average abundance $\left(a_{i}\right)$ which measures the affected area share when that weed occurs (Table 1). Finally, in order to quantify the site-specific damage controlling effect of specific herbicides, a weed-row vector $w$ with size $i 32 \times 1$ depicts for each municipality $m$ the probability that a weed occurs. The three vectors - probability of weed occurrence $w$, affected share $a$, and damage control for each weed $h$-define jointly the control success $z$ for each herbicide strategy $j$ in the different municipalities $m$ :

$$
z_{m, j}=\sum_{i}^{32} w_{m, i} \cdot a_{i} \cdot h_{j, i} \cdot
$$

Eq. (3) presents the post-sowing weed controlling effects. Since we use probabilities for the determination of the damage controlling effect, the equation is dimensionless. In a similar manner, a vector $v_{m, j}$ can be constructed that accounts for pre-sowing weed management effects (denoted as $b_{j, i}$ ):

$$
\mathrm{v}_{\mathrm{m}, \mathrm{j}}=\sum_{\mathrm{i}}^{32} \mathrm{w}_{\mathrm{m}, \mathrm{i}} \cdot \mathrm{a}_{\mathrm{i}} \cdot \mathrm{b}_{\mathrm{j}, \mathrm{i}} .
$$

\subsection{Choice of Functional Form and Implementing the Damage Controlling Effect}

Inserting the damage control success expression from Eq. (3) in Eq. (2) yields the following specification:

$$
D_{m, j}=1-e^{-\left(\beta_{0}+\beta_{1} \cdot \sum_{i}^{32} w_{m, i} \cdot a_{i} \cdot h_{j, i}\right)^{2}}, \quad \beta_{0}, \beta_{1} \geq 0 .
$$

One of the remaining issues is to determine the form of the production function. We follow Bosnić and Swanton (1997), Swinton et al. (1994), Swinton and King (1994) as well as Kropff et al. (1992), and use the rectangular hyperbolic approach of Cousens (1985) and Cousens et al. (1987), which allows accounting for biological effects such as time of emergence. Thus, the yield function in relation to weed control is defined as follows: 
$y_{m, t, b, h}^{*}=y_{m, t}^{a} \cdot\left[1-I \cdot \frac{D_{m . j}}{100 \cdot\left(e^{C \cdot T}+I \cdot \frac{D_{m, j}}{A}\right)}\right]$.

In this function, $y_{a}$ is the attainable yield when no weeds are present, $I$ is the percent yield loss as $D_{m, j}$ approaches 0 (i.e. $D_{m, j}$ is not yet 0$)^{1}, A$ is the percent yield loss as $D_{m, j}$ approaches infinity, $T$ is the time of crop emergence and growth in relation to the weed emergence and growth, measured in growing degree days, which is the sum of the average temperature of each day and $C$ is the rate at which the yield loss $I$ increases as $T$ becomes smaller (i.e. weed pressure increases). Fungi and insects are of limited relevance in German maize production or can be controlled by seed dressing or resistant varieties such that except for herbicides usually no other pesticides are applied (JKI, 2016). Thus, the attainable yield $y^{a}$ is defined as the potential water-limited yield under given climatic and soil conditions, i.e. under no nutrient stress. The shape of the function is illustrated in Fig. 1. Nevertheless, using solely the yield term (6) neglects pre-sowing weed controlling practices depicted by $v_{m, j}$. Accounting for that, the expected yield $y^{*}$ for a specific strategy becomes:

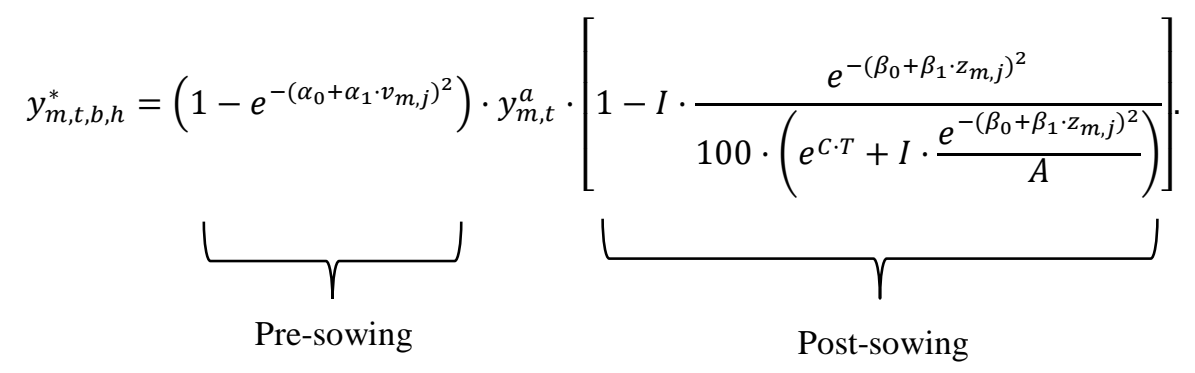

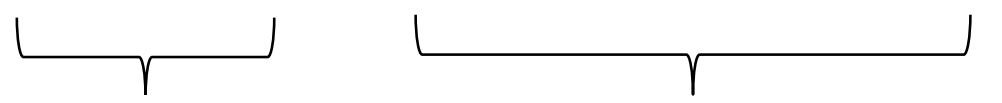

\footnotetext{
${ }^{1}$ Originally, Cousens (1985) used average plants per $\mathrm{m}^{2}$. We will use the abundance of a single weed for our purpose, in relation to Table 1.
} 


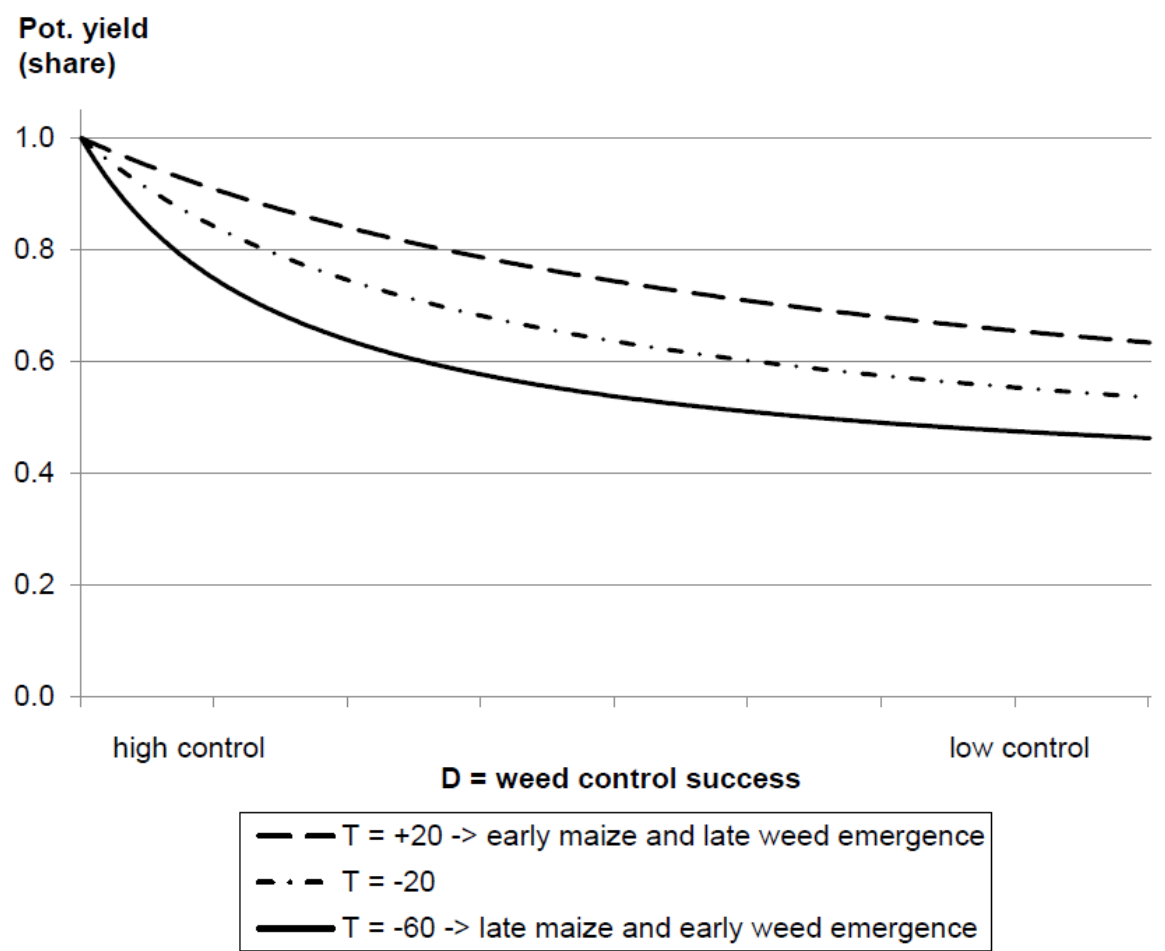

Fig. 1. Shape of the rectangular hyperbolic yield function from Eq. (6) for different levels of $T$.

\subsection{Parameterisation and Pesticide Application Restrictions}

In order to calibrate the model and to parameterise the production function, we conducted expert interviews with the senior herbicide consultant and three regional herbicide consultants of the chamber of agriculture from NRW who identified strategies in regions of NRW differentiated by soil types. ${ }^{2}$ Furthermore, we collected

\footnotetext{
${ }^{2}$ Regarding herbicide strategies, three major soil types can be distinguished in NRW: sandy soils where herbicides against Panicoideae-varieties are applied, clayey soils where strategies against Alopecurus myosuroides are preferred and good loamy soils where simple and cheap strategies are used. Eight municipalities were selected where current weed control strategies are known (4x sandy soils due to the relevance in maize production, 2x good loamy soils and 2x clayey soils). We decided against the alternative way of estimating different parameters for different soil types because municipalities where a mix of soil types is observed accordingly also apply a mix of strategies. Additionally, data on yields for different soil types would be required which are not available. Applying different production
} 
data on the observed yield $\bar{y}_{m, t}$ in each municipality $m$ which should reflect the current weed control practise (IT NRW, 2016). In order to estimate the parameters of interest $\left(\alpha_{0}, \alpha_{1}, \beta_{0}\right.$ and $\left.\beta_{1}\right)$, we determine the parameter values which minimise the error term between the observed yields and the yields simulated with the most frequently used control strategies in selected municipalities where a clear assignment between expert knowledge on strategies used and weeds occurring could be made, i.e. municipalities which have homogeneous soil types but different potential yields: ${ }^{3}$

$$
\min \varepsilon=\sum_{\mathrm{m}}^{8}\left(\mathrm{y}_{\mathrm{m}, \mathrm{t}^{*}, \mathrm{~b}^{*}, \mathrm{~h}^{*}}-\overline{\mathrm{y}}_{\mathrm{m}, \mathrm{t}}\right)^{2}
$$

As outlined in section 0 , further restrictions are considered during the non-linear estimation process to identify the parameters. Once the parameters are identified and inserted into the production function, optimal strategies can be determined for each $m$ and $t$ according to Eq. (1), i.e. profits can be maximised for each municipality and year by choosing pre- $\left(S_{b, m, t}\right)$ and post-sowing $\left(S_{h, m, t}\right)$ shares for the control strategies:

$$
\begin{aligned}
& E\left(\pi_{\mathrm{m}, \mathrm{t}}\right)=\sum_{\mathrm{b}=1}^{24} \sum_{\mathrm{h}=1}^{55} \mathrm{E}\left(\pi_{\mathrm{m}, \mathrm{t}, \mathrm{b}, \mathrm{h}}\right) \cdot \mathrm{S}_{\mathrm{b}, \mathrm{m}, \mathrm{t}} \cdot \varphi_{\mathrm{b}, \mathrm{glyphosate}} \cdot \mathrm{S}_{\mathrm{h}, \mathrm{m}, \mathrm{t}}, \\
& \max \pi=\sum_{\mathrm{m}=1}^{377} \sum_{\mathrm{t}=1}^{2} \mathrm{E}\left(\pi_{\mathrm{m}, \mathrm{t}}\right) .
\end{aligned}
$$

$\varphi$ is the information matrix whether glyphosate is allowed in the analysed scenarios. $S_{b, m, t}$ and $S_{h, m, t}$ are the shares of the selected control strategies of the farmers for pre(b) and post-sowing $(h)$ weed management and $E\left(\pi_{m, t, b, h}\right)$ is the profit for each

functions per soil type would force us to decide for one specific function, although a mix of soil types is predominant.

${ }^{3}$ Another possibility is to use expert knowledge for the parameter estimation as done by Femenia and Letort (2016). In a study by Deen et al. (1993), the parameter value is assumed with respect to the efficacy of the herbicide. 
strategy which reflects the expected yield, related fertiliser and other costs including the costs for weed control.

Some further details need to be reflected during estimation and simulation. Firstly, we assume that the strategy needs to be changed from year to year to avoid building up resistance against specific AS in the weed population. More specifically, we classified the strategies based on the Herbicide Resistance Action Committee (HRAC, 2005 ) into groups and added a constraint, which prevents that strategies from the same groups are used in two consecutive years (Eq. (11). Second, special requirements for nicosulfuron-containing strategies have to be included since this AS is only allowed to be applied every second year by law (code NG327 for the use of plant protection products; Eq. (12). Those restrictions can be implemented as:

$$
\begin{aligned}
& \sum_{\mathrm{t}=1}^{2}\left(\sum_{\mathrm{b}=1}^{24}\left(\mathrm{~s}_{\mathrm{b}, \mathrm{m}, \mathrm{t}} \cdot \eta_{\mathrm{b}, \mathrm{HRAC}}\right)+\sum_{\mathrm{h}=1}^{55}\left(\mathrm{~s}_{\mathrm{h}, \mathrm{m}, \mathrm{t}} \cdot \eta_{\mathrm{h}, \mathrm{HRAC}}\right)\right) \leq \frac{|\mathrm{t}|}{2} \forall \mathrm{m} \wedge \text { HRAC } \\
& \sum_{\mathrm{t}=1}^{2} \mathrm{~s}_{\mathrm{h}, \mathrm{m}, \mathrm{t}} \cdot \varphi_{\mathrm{h}, \text { nicosulfuron }} \leq \frac{|\mathrm{t}|}{2} \forall \mathrm{m},
\end{aligned}
$$

where $\varphi$ and $\eta$ are information matrices of whether post-sowing strategy $j$ contains nicosulfuron and is classified as a certain $\operatorname{HRAC}[0,1]$.

The model is written in General Algebraic Modelling System (GAMS) code (Appendix A). We simulate optimal herbicide strategies under a baseline where glyphosate can be applied throughout the two periods and a counterfactual where glyphosate is banned. We conduct sensitivity analyses with regard to the attainable yield (the attainable yield is increased by $10 \%$ in $t_{1}$ and $15 \%$ in $t_{2}$ ), the green maize price ex field $P(€ 2.80 / \mathrm{dt}, € 3.30 / \mathrm{dt}$ and $€ 3.80 / \mathrm{dt}$, dt $=$ deciton $)$ and the difference between weed and crop occurrence $T$ (40 to -90), so that effects of higher or lower prices and higher or lower weed pressure can be seen. The latter is depicted by earlier or later maize emergence compared to weeds, e.g. $\mathrm{T}=0$ means that maize and weeds emerge at the same time, $\mathrm{T}=-50$ means that weeds have an advantage in emergence of, on average, five days with an average temperature of $10^{\circ}$. Of course, farmers try to keep the level of $T$ large (i.e. close to zero or even positive) to increase the 
competitiveness of maize, and pre-sowing weed management is therefore done close to sowing. Based on model results derived across different municipalities and scenarios, we test the following five hypotheses: H1) average post-sowing strategies change in case of a glyphosate ban, H2) costs for weed management increase in case of a glyphosate ban, H3) working force demand increases in case of a glyphosate ban, H4) the gross margin decreases in case of a glyphosate ban, and H5) yields significantly decrease in case of a glyphosate ban. ${ }^{4}$ To this end, t-tests and WilcoxonMann-Whitney tests are used.

\section{Data}

We focus on the most important weeds in maize cultivation for our case study region (defined as more than 10\% degree of presence, following the samples of Mehrtens et al. (2005) and Mol et al. (2015). Additionally, Digitaria ischaemum and Mercurialis annua were included; weeds which are of importance in specific regions of NRW as they are also listed in the agricultural recommendations (see resulting list in Table 1). Information on the occurrence of weeds is taken from the $2.88 \times 2.75 \mathrm{~km}$ distribution raster of Germany's pteridophytes and flowering plants (NetPhyD and BfN, 2013; see also www.floraweb.de), and mapped via GIS operations to municipality areas. We included only the 377 municipalities of NRW which reported maize cultivation in recent years. Each municipality receives weed specific occurrence probabilities which reflect the area weighted average of raster cells where each weed was observed (see data for Alopecurus myosuroides, Digitaria ischaemum, Setaria viridis and Chenopodium spp. in Fig. 2). Information on the average abundance, i.e. the share of affected area when a weed is observed and not controlled, is used from long-term field trials (Table 1).

We consider those herbicides (combinations) that are recommended by the Chamber of Agriculture of North Rhine Westphalia (LWK NRW, 2015a) and the Bavarian State Research Centre for Agriculture (LfL, 2016). These recommendations

\footnotetext{
${ }^{4}$ For the hypotheses, we use the average of the periods $t_{1}$ and $t_{2}$.
} 
are widely used in agricultural extension and also published in agricultural magazines. Because of lack of data on how different doses affect weed control, we use the recommended dose in each strategy instead of trying to also solve for an optimal rate (Pannell, 1990). However, these doses may vary between strategies comprising the same AS. In total, 55 different post-sowing herbicide strategies were defined, where one reflects zero control, 6 are mechanical only and the remaining 48 apply herbicides once or twice (see Appendix B). For each of those 55 strategies, data by the LfL (2016) and the LWK NRW (2015a) define the suppressing efficiency against each of the 32 weeds in the interval $[0,1]$. A value of 1 characterises total eradication, a value of zero indicates no impact on the weed, and a value between zero and one was assigned if part of the population is removed. To cope with gaps in this database, we use manufacturer information (obtained from product brochures) to specify herbicide efficacy. Thereby, in general three categories are displayed: well or very well controllable, sufficiently controllable and not sufficiently controllable. For the first category, we assume an efficacy of 0.90 , for the second category 0.33 and for the third category null efficacy. 
Table 1. Maize grass-weeds and weeds implemented in the output damage function approach

\begin{tabular}{|c|c|c|c|}
\hline Name & $\begin{array}{r}\text { Average } \\
\text { abundance (\%) }\end{array}$ & Name & $\begin{array}{r}\text { Average } \\
\text { abundance }\end{array}$ \\
\hline Grass-weeds: & & Fumaria officinalis & 2.0 \\
\hline Alopecurus myosuroides & $21.3^{+}$ & Galinsoga parviflora & 12.0 \\
\hline Digitaria ischaemum & $21.3^{+}$ & Galium aparine & 7.0 \\
\hline Echinochloa crus-galli & 22.0 & Geranium pusillum & 6.0 \\
\hline Elymus repens & $21.3^{+}$ & Lamium spp. & 6.0 \\
\hline Poa annua, $P$. trivialis & 2.0 & Matricaria spp. & 13.0 \\
\hline Setaria viridis & 40.0 & Mercurialis annua & $6.8^{+}$ \\
\hline Broad-leaved weeds: & & Persicaria lapathifolia & 11.0 \\
\hline Amaranthus retroflexus & 13.0 & Persicaria maculosa & 3.0 \\
\hline Atriplex patula & 1.0 & Polygonum aviculare agg. & 3.0 \\
\hline Brassica napus & 18.0 & Rumex obtusifolius & 4.0 \\
\hline Capsella bursa-pastoris & 5.0 & Solanum nigrum & 3.0 \\
\hline Chenopodium spp. & 20.0 & Sonchus spp. & 2.0 \\
\hline Cirsium arvense & 4.0 & Stellaria media agg. & 6.0 \\
\hline Convolvulus arvensis & 2.0 & Thlaspi arvense & 3.0 \\
\hline Equisetum arvense, $E$. & $6.8^{+}$ & Veronica spp. & 2.0 \\
\hline Fallopia convolvulus & 12.0 & Viola arvensis & 5.0 \\
\hline
\end{tabular}

Note: Abundance-values marked with $\mathrm{a}^{+}$are estimates according to mean values of grass weeds or broad-leaved weeds. Data on year to year variation of the abundance were not found. Brassica napus was included for potential extension of the model by other crops (crop rotation). Source: Meinlschmidt et al. (2008). 

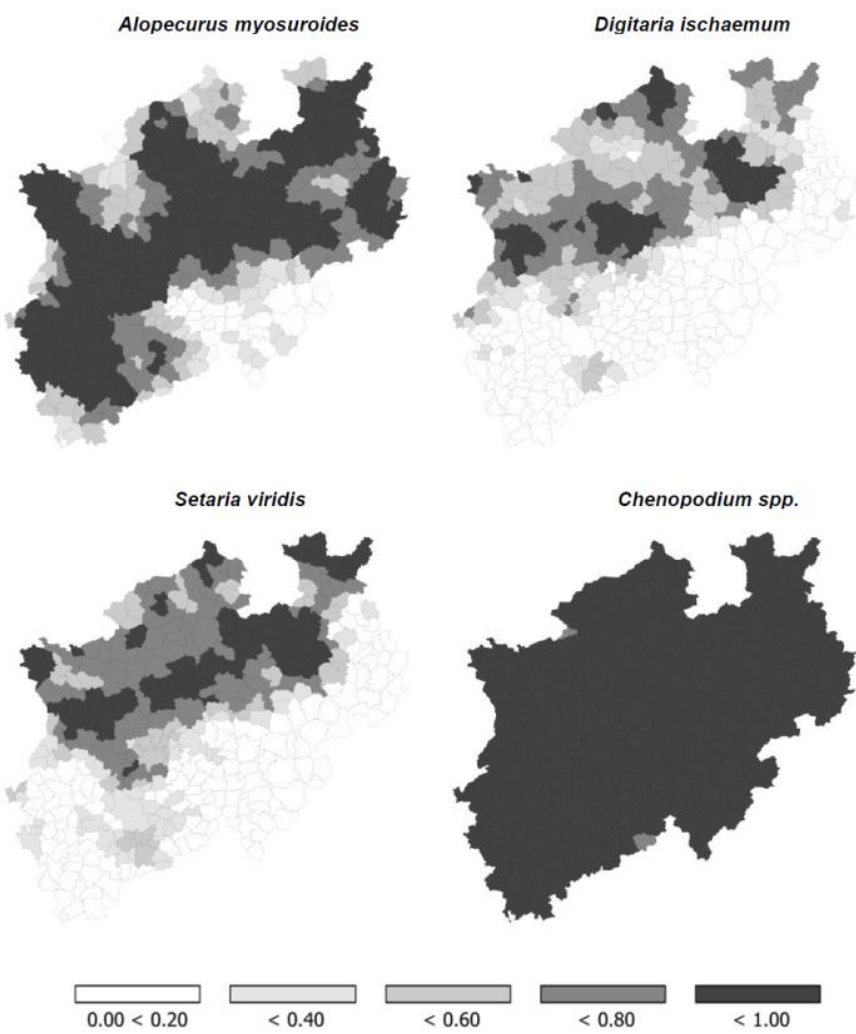

Fig. 2. Spread, measured as probability of occurrence, of four selected weeds in NRW. Reference: NetPhyD and BfN (2013), raster data converted to municipality borders.

To quantify the efficacy of the mechanical strategies, we combine information from extensive or organic farming systems with expert knowledge (Jacquet et al., 2011; Oskam, 1997). Data on mechanical post-sowing techniques could be found in Kees (1984, unpub., cit. from Hoffmann, 1990). Additionally, we consulted the organic farming expert of the Chamber of Agriculture from Lower Saxony for information on the mechanical harrowing and hoeing frequency, and their effect on specific weeds. ${ }^{5}$ There are 24 different pre-sowing plant protection strategies in our model, consisting of mouldboard ploughing, different chisel ploughing and harrowing

\footnotetext{
${ }^{5}$ On average, an effective mechanical weed management in maize is reached with three runs of harrowing and two runs of hoeing. If maize emerges early, fewer runs are necessary, and more if maize emerges late. In general, root weeds are more troublesome to control than other ones. However, blind harrowing can also be effective against root weeds.
} 
combinations and of glyphosate combinations. ${ }^{6}$ Except for glyphosate, no other herbicides are allowed before sowing (Kehlenbeck et al., 2015). We could not find unambiguous data about the yield increasing or decreasing effect of different tillage systems. Therefore, with respect to the weed controlling capacity of conventional and conservation tillage, both strategies have almost the same yield potential. Conventional tillage has only slight advantages in weed control.

Data about actual yields are available at county-level (53 counties in NRW; IT NRW, 2016), and $\bar{y}$ is the five year average of the actually observed yield from 2011 and 2015 (Fig. 3). A 5\% increase of the expected yield is assumed for the second year $t_{2}$. Oerke (2006) estimated a 5\% yield loss from weeds in Western European maize production with usual weed control strategies $\left(y^{a}=1.05 \bar{y}\right)$. For information about maximum losses under zero control (scalar $A$ in Eq. (7), we draw on field trials by Söchting and Zwerger (2012). Maize yields with herbicide treatment were up to 63.8\% higher compared to the untreated control group $(A=63.8 \%)$. For $I$ and $C$ in Eq. (7), we rely on Bosnić and Swanton (1997), who estimated $I=-0.3 \%$ and $C=0.017$. Further restrictions of the estimation model are that the no-till pre-sowing strategy with no herbicide application has to achieve a yield level between $86 \%$ and $90 \%$ and that the ploughing strategy has to be larger than 95\% (Gehring et al., 2012). The zero control post-sowing strategy is fixed at $86 \%$ for normal weed emergence (in relation to the field trials of Söchting and Zwerger, 2012). Based on this data, the estimates from Eq. (8) are as follows: $\varepsilon$ has a value of $0.8-4.0 \%$ of $E(y)$ depending on the municipality in the parameterisation. The best fit parameter values are $\alpha_{0}=1.304$, $\alpha_{1}=0.770, \beta_{0}=0.724$ and $\beta_{1}=0.244$ (estimated at $\mathrm{T}=0$ ).

Herbicide's costs are based on 2015 recommended retail prices from a German agricultural trader (Roth Agrarhandel, 2015; see Appendix B). For labour costs, $€ 17.5 / \mathrm{h}$ are assumed. In our study region, organic fertiliser is no limiting production factor (see Gömann et al., 2010 for details) so that we assume that slurry is for free. The most relevant cost parameters are presented in Table 2.

\footnotetext{
${ }^{6}$ As glyphosate containing product, we chose Roundup® PowerFlex.
} 


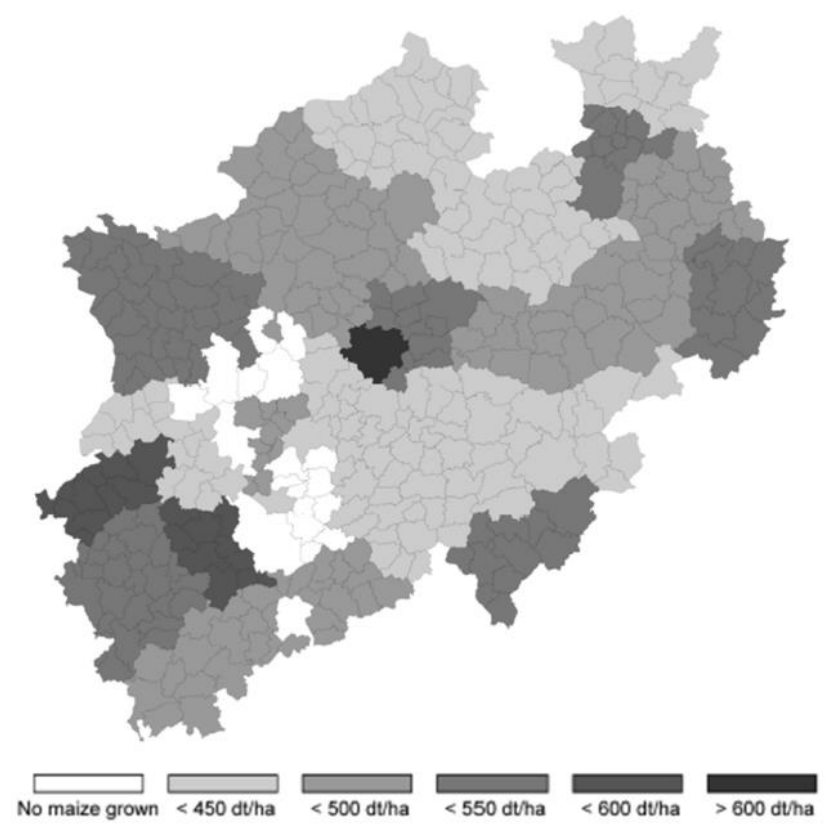

Fig. 3. Silage maize yields in different counties of NRW (five-year average of 20112015).

Reference: IT NRW (2016). 
Table 2. Machinery costs and other inputs related to maize growing

\begin{tabular}{|c|c|c|c|c|}
\hline Activity & $\begin{array}{c}\text { Sub- } \\
\text { activity }\end{array}$ & $\begin{array}{l}\text { Work hours } \\
\text { (h/ha) }\end{array}$ & $\begin{array}{l}\text { Fix and variable } \\
\text { machinery costs }\end{array}$ & $\begin{array}{l}\text { Other } \\
\text { inputs }\end{array}$ \\
\hline \multicolumn{5}{|c|}{ Weed control-related activities: } \\
\hline $\begin{array}{l}\text { Chisel plough/Cultivator } \\
(4.5 \mathrm{~m})\end{array}$ & & 0.44 & 24.17 & \\
\hline $\begin{array}{l}\text { Mouldboard plough and } \\
\text { packer }(1.4 \mathrm{~m})\end{array}$ & & 1.73 & 66.97 & \\
\hline Pesticide sprayer (24m) & & 0.17 & 6.90 & \\
\hline Harrow (9m) & & 0.17 & 11.09 & \\
\hline Hoe $(6 m)$ & & 0.72 & 30.03 & \\
\hline \multicolumn{5}{|c|}{ Other activities: } \\
\hline $\begin{array}{l}\text { Inspection (share, every } \\
5^{\text {th }} \text { year) }\end{array}$ & & 0.04 & 0.26 & - \\
\hline \multirow[t]{2}{*}{$\begin{array}{l}\text { Manure application }(25 \\
\left.\mathrm{m}^{3} / \mathrm{ha}\right)\end{array}$} & & 0.74 & 50.23 & - \\
\hline & Manure & - & - & $€ 0.00 / \mathrm{ha}$ \\
\hline Precision drill (6m- & & 0.53 & 41.72 & - \\
\hline $\begin{array}{l}\text { Direct precision drill } \\
\text { (59\% increase to normal } \\
\text { precision drill, 20\% } \\
\text { discount on light soils) }\end{array}$ & Seed & 0.53 & 66.31 & $€ 233.20 / \mathrm{ha}$ \\
\hline $\begin{array}{l}\text { Mounted fertiliser } \\
\text { spreader (amount } \\
\text { depends on } E(y))\end{array}$ & & $0.00-0.29$ & $0.00-6.14$ & \\
\hline \multirow[t]{5}{*}{$\begin{array}{l}\text { Liming (share, every } 3^{\text {rd }} \\
\text { year) }\end{array}$} & & 0.19 & 12.47 & \\
\hline & $\mathrm{N}$ & & & $€ 1.10 / \mathrm{kg}$ \\
\hline & $\mathrm{P}_{2} \mathrm{O}_{5}$ & & & $€ 0.87 / \mathrm{kg}$ \\
\hline & $\mathrm{K}$ & & & $€ 0.77 / \mathrm{kg}$ \\
\hline & $\mathrm{Ca}$ & & & $€ 0.05 / \mathrm{kg}$ \\
\hline $\begin{array}{l}\text { No harvest cost, sell ex } \\
\text { field }\end{array}$ & & - & - & \\
\hline
\end{tabular}

Note: Diesel consumption for mouldboard ploughing is assumed to be $30 \%$ higher/lower on heavy/light soils (for chisel ploughing 20\% higher/lower). References: Achilles et al. (2016), fertiliser prices from LfL (2016), weight-shares from LWK NRW (2015b). 


\section{Results}

The results are presented in two sections. In the first section, the results from the different simulations and scenarios are shown and described. The second one addresses the hypotheses testing. ${ }^{7}$

\subsection{Descriptive Results}

Fig. 4 presents for three price levels ${ }^{8}$ the chosen pre-sowing strategies as a share of municipalities where they are applied, on average of the two years $t$. The application of glyphosate in a strategy is found to be on average optimal in about $5 \%$ to $25 \%$ of the municipalities (depending on prices and weed pressure expressed as $T$ ). In the other municipalities, conservation tillage with mechanical strategies consisting of one or two chisel ploughings and/or one to three harrowing passes is the most profitable. Glyphosate containing strategies are more profitable when applied closer to maize emergence, i.e. close before sowing or even close after sowing. The later maize emerges compared to weeds, the less glyphosate is applied. In case of a ban, the above mentioned mechanical strategies are used throughout, but mouldboard ploughing is not used in any year. As conservative mechanical control suppresses weeds not as effectively as non-selective herbicides, glyphosate use is higher in $t_{2}$ where the attainable yield is assumed higher. Only mechanical control is observed under a ban since no alternative herbicides are licensed for pre-sowing application.

\footnotetext{
${ }^{7}$ The results of the sensitivity analysis with regard to water limited potential yields are available as Appendix C, the most important findings are discussed in the following where appropriate.

${ }^{8}$ We use the price levels of $€ 2.80 / \mathrm{dt}, € 3.30 / \mathrm{dt}$ and $€ 3.80 / \mathrm{dt}$. For the region of NRW, the price levels of $€ 3.30 / \mathrm{dt}$ or even $€ 3.80 / \mathrm{dt}$ are under current conditions more realistic than the lower price of $€ 2.80 / \mathrm{dt}$.
} 


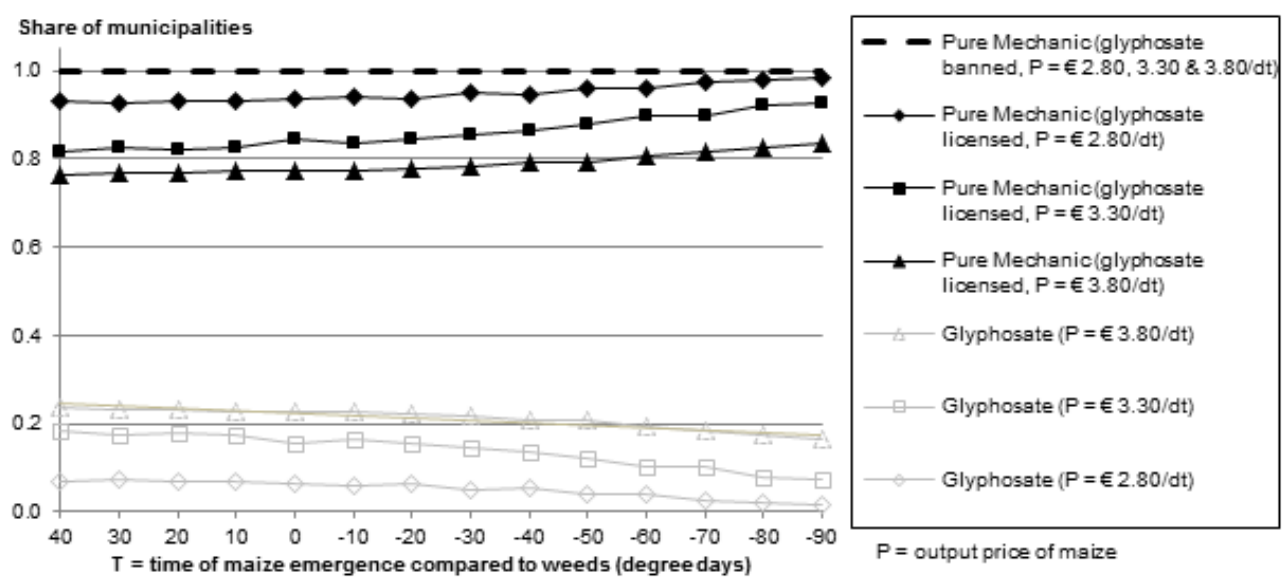

Fig. 4. Shares of used pre-sowing strategies (average of $t_{1}$ and $t_{2}$ of each municipality). Note: A scenario in which glyphosate is licensed is compared to a scenario with a glyphosate ban. The figure shows the results for the three analysed price levels at different weed pressure levels (expressed as $T)$.

Regarding selective herbicide use after sowing, we observe that with a later emergence of silage maize compared to weeds, i.e. a higher weed pressure reflected by a more negative $T$, more expensive herbicide strategies get more profitable. This implies that the share of mechanical strategies decreases (Fig. 5). Higher silage maize prices reinforce this. Comparing the change in $T$ from +40 to -90 , for example, implies an increase in weed control costs from $€ 78$ /ha up to $€ 115 /$ ha at $\mathrm{P}=€ 3.80 / \mathrm{dt}$, compared to an increase from $€ 66 /$ ha to $€ 95 /$ ha at $\mathrm{P}=€ 2.80 / \mathrm{dt}$ (Appendix $\mathrm{C}$ ). The composition of the chosen strategies as a function of $T$, i.e. maize relative to weed emergence, is summarised in Fig. 6 for the glyphosate licensed-scenario and an output price of $€ 3.80 / \mathrm{dt}$. In both scenarios, i.e. for glyphosate being licensed and banned, the most profitable AS shift from nicosulfuron, prosulfuron and S-metolachlor to terbuthylazine, mesotrione, pethoxamid, flufenacet, foramsulfuron, iodosulfuron and thiencarbazone.

Assuming higher potential water limited yields let the model simulate higher shares of glyphosate usage (up to $21 \%$ at $\mathrm{P}=€ 3.30 / \mathrm{dt}$ and $26 \%$ at $\mathrm{P}=€ 3.80 / \mathrm{dt}$ ) and also to faster changes in the use of the different AS (i.e. higher shares of terbuthylazine, flufenacet, foramsulfuron, iodosulfuron and thiencarbazone can be observed) (Appendix C). Additionally, spending for weed management increase (averagely at a price of $€ 3.80 / \mathrm{dt}$ an increase from $€ 88 / \mathrm{ha}$ at $\mathrm{T}=-30$ to $€ 122 /$ ha at $\mathrm{T}=-90$ ). 


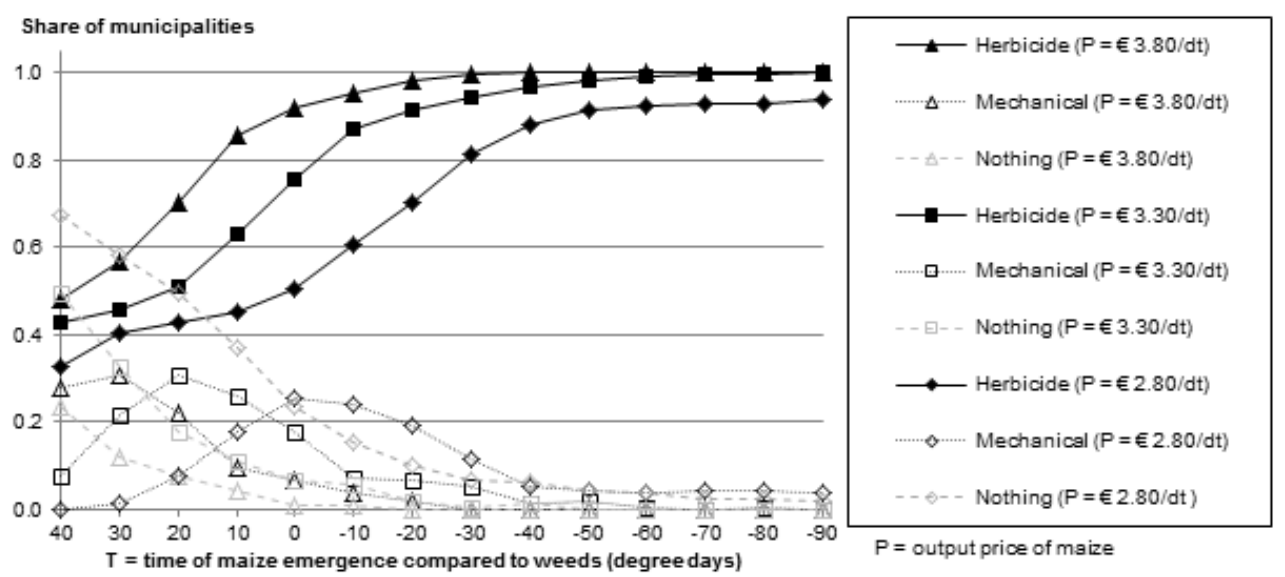

Fig. 5. Shares of post-sowing strategies as average of $t_{1}$ and $t_{2}$ (scenario with glyphosate licensed).

Note: The figure shows the categorisation of the post-sowing strategies in Herbicide, Mechanical and Nothing. Three price levels and different weed pressure levels (expressed as $T$ ) are analysed.

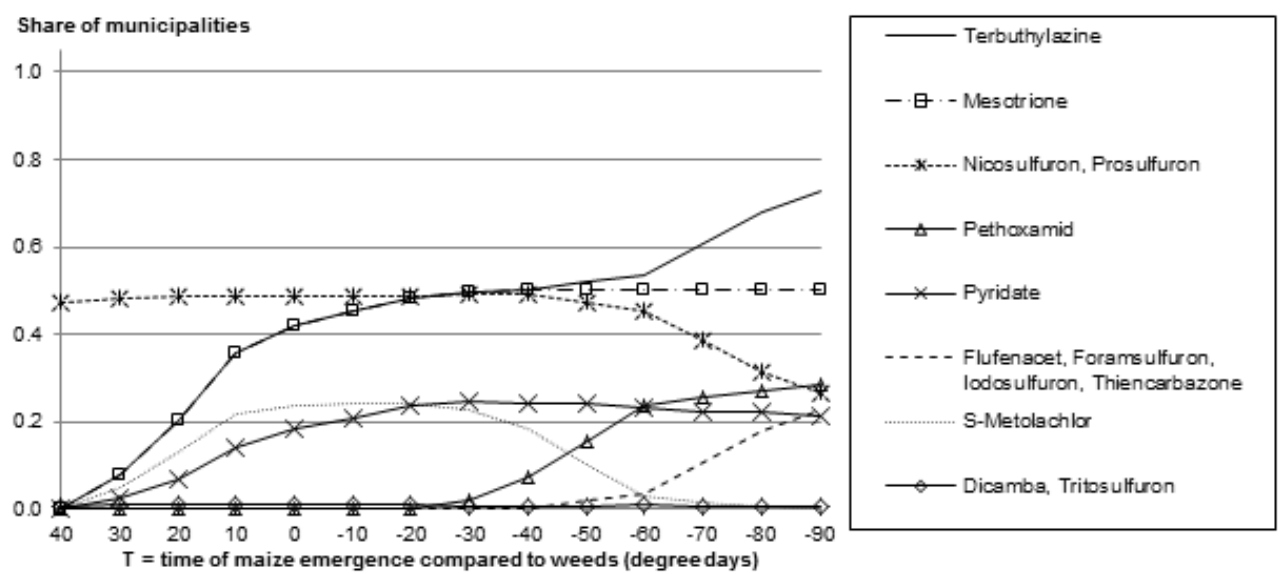

Fig. 6. Shares active substances in of post-sowing strategies (glyphosate licensed, $\mathrm{P}=$ $€ 3.80 / \mathrm{dt}$, average of $t_{1}$ and $t_{2}$ ).

Note: The figure shows how often an active substance is used on average over the municipalities. For example, a level of $60 \%$ for terbuthylazine means that this substance is contained in the weed management strategy, on average of the two years, in 226 of the 377 municipalities each year.

\subsection{Hypotheses Testing}

Table 3 shows the results of the hypotheses testing for the price levels of $€ 2.80 / \mathrm{dt}$ and $€ 3.80 /$ dt. Differences of mean values over all municipalities are given for different levels of $T$ and for prices of $€ 2.80 / \mathrm{dt}$ and $€ 3.80 / \mathrm{dt}$. H1 states changes in post-sowing 
AS use after a ban. However, the composition of the different AS changes only in few municipalities, but those changes are overall not significant.

We cannot reject $\mathrm{H} 2$ that weed control becomes more expensive under a ban. We find that in municipalities where glyphosate was used in the benchmark, a significantly different amount is spent on weed management under a ban (plus $€ 4-6 /$ ha. The effect decreases with the higher price of $€ 3.80 / \mathrm{dt}$ due to the higher intensity of pre-sowing weed management in the benchmark scenario at the higher price level. The cost increase stems from substituting glyphosate mostly with one or two passes of chisel ploughing. Note that sowing is assumed to be cheaper after two passes compared to only a single pass of chisel ploughing (and also cheaper compared to glyphosate application only). The application of mechanical strategies leads to a significant increase in labour demand (H3). That effect, however, decreases if $T$ is lower, i.e. the weed pressure after sowing is high. In the latter case, more expensive post-sowing strategies with selected herbicides are used instead.

Generally, expected gross margins vary highly across municipalities reflecting yield differences. Furthermore, the later maize emerges compared to weeds, the lower the gross margin will be. A glyphosate ban causes in our simulation, on average over all glyphosate-using municipalities, decreases of the gross margins (already accounting for higher costs for labour) of about $€ 1-2 /$ ha, with maximal reductions of $€ 9 /$ ha (for $\mathrm{P}=€ 2.80 / \mathrm{dt}$ ) and $€ 13 /$ ha (for $\mathrm{P}=€ 3.80 / \mathrm{dt}$ ) over the two year growing period. In single years, however, costs can be higher if our assumptions on resistance management are neglected. Thus, the loss of gross margin due to the ban of glyphosate is moderate and the null hypothesis of no change cannot be rejected (see Table 3, row H4). The reasons for the moderate gross margin reduction although overall costs increase are again due to the cost savings in precision drilling when glyphosate is substituted by two passes of chisel ploughing. Fig. 7 presents the distribution of those losses over the federal state of NRW for different levels of $T$ and at $\mathrm{P}=€ 3.80 / \mathrm{dt}$. First, the differences between the regions are due to the differences in attainable yield levels (Fig. 3). Second, differences are dependent on soil types: losses are higher on clayey soils due to relatively high cultivation costs and they are higher on sandy soils due to 
cost saving when applying direct precision drilling (or strip till). Third, we find that the overall weed pressure $\left(\sum_{i}^{32} w_{m, i} \cdot a_{i} ;\right.$ e.g. by spread of Panicoideae-varieties or Alopecurus myosuroides, see also Fig. 2) is higher in municipalities with lower gross margin losses under a glyphosate ban. This is at first glance a somewhat counterintuitive observation. The reason behind this is that our model simulates already under the benchmark in the light of a high pressure from different weeds a lower pre-sowing weed control intensity, as the gross margin is higher when some yield losses are accepted instead of controlling with high costs multiple weeds. Under a ban of the non-selective herbicide, the shift to mechanical pre-sowing strategies is then also not accompanied by expensive post-sowing use of selective herbicides while the overall already higher weed pressure and thus the attained yield is not much affected.

The reduced plant protection intensity under a ban is reflected in significantly decreased yields by about $0.5-1 \%$ (H5), which turns out as more profitable than maintaining the control effort with more expensive strategies (difference is significant at higher levels of $T$ and the two presented prices in Table 3 ).

The results of the hypothesis testing do not change much when a higher potential water limited yield is assumed. The most important change is some additional cost increase in weed control. 
Table 3. Differences between glyphosate-ban-scenario and glyphosate-licensed-scenario (mean across the glyphosate using municipalities) and results of hypotheses testing

\begin{tabular}{|c|c|c|c|c|c|c|c|c|c|c|c|c|c|c|c|}
\hline & \multirow{2}{*}{$\begin{array}{r}\text { Maize emergence } \\
\text { Price }(€ / d t)\end{array}$} & \multicolumn{2}{|c|}{$\mathbf{T}=\mathbf{3 0}$} & \multicolumn{2}{|c|}{$\mathrm{T}=\mathbf{1 0}$} & \multicolumn{2}{|c|}{$T=-10$} & \multicolumn{2}{|c|}{$T=-30$} & \multicolumn{2}{|c|}{$\mathrm{T}=-\mathbf{5 0}$} & \multicolumn{2}{|c|}{$T=-70$} & \multicolumn{2}{|c|}{$T=-90$} \\
\hline & & 2.80 & 3.80 & 2.80 & 3.80 & 2.80 & 3.80 & 2.80 & 3.80 & 2.80 & 3.80 & 2.80 & 3.80 & 2.80 & 3.80 \\
\hline \multirow{17}{*}{ 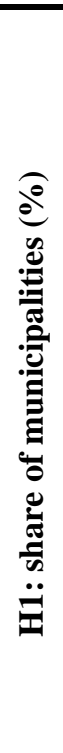 } & No Herbicide & 1.9 & $\overline{4.0}$ & 2.0 & 1.7 & 6.5 & 2.9 & 7.9 & - & - & - & - & - & - & - \\
\hline & Mechanic & - & - & - & 1.7 & - & 2.9 & 2.6 & - & - & - & - & - & - & - \\
\hline & Nothing & 1.9 & 4.0 & 2.0 & - & 6.5 & - & 5.3 & - & - & - & - & - & - & - \\
\hline & Herbicide & -1.9 & -4.0 & -2.0 & -1.7 & -6.5 & -2.9 & -7.9 & - & - & - & - & - & - & - \\
\hline & Dicamba & - & - & 2.0 & - & - & -1.8 & - & -0.6 & - & - & - & 0.7 & - & - \\
\hline & Flufenacet & - & - & - & - & - & - & - & - & - & - & - & -0.7 & - & 0.8 \\
\hline & Foramsulfuron & - & - & - & - & - & - & - & - & - & - & - & -0.7 & - & 0.8 \\
\hline & Iodosulfuron & - & - & - & - & - & - & - & - & - & - & - & -0.7 & - & 0.8 \\
\hline & Mesotrione & - & - & - & 1.2 & & 1.8 & -2.6 & 2.4 & - & -2.5 & - & 1.5 & - & 1.6 \\
\hline & Nicosulfuron & -1.9 & -4.0 & -3.9 & -2.9 & -6.5 & -2.9 & -5.3 & -1.8 & - & 2.5 & - & -1.5 & - & -2.4 \\
\hline & Pethoxamid & - & - & - & - & - & - & - & - & - & -0.6 & - & 2.2 & - & 0.8 \\
\hline & Prosulfuron & -1.9 & -4.0 & -3.9 & -2.9 & -6.5 & -2.9 & -5.3 & -1.8 & - & 2.5 & - & -1.5 & - & -2.4 \\
\hline & Pyridate & - & - & - & 1.2 & - & -1.2 & - & 2.4 & - & -1.9 & - & -0.7 & - & 0.8 \\
\hline & S-Metolachlor & - & - & - & - & - & 2.9 & -2.6 & - & - & 0.6 & - & - & - & - \\
\hline & Terbuthylazine & - & - & - & 1.2 & - & 1.8 & -2.6 & 2.4 & - & -2.5 & - & 0.7 & - & 2.4 \\
\hline & Thiencarbazone & - & - & - & - & - & - & - & - & - & - & - & -0.7 & - & 0.8 \\
\hline & Tritosulfuron & - & - & 2.0 & - & - & -1.8 & - & -0.6 & - & - & - & 0.7 & - & - \\
\hline \multirow{2}{*}{$\begin{array}{l}\stackrel{\widetilde{J}}{\tilde{\Psi}} \\
\ddot{\ddot{I}}\end{array}$} & \multirow{2}{*}{ Weed management costs } & 6.19 & 5.48 & 5.83 & 5.24 & 5.88 & 4.89 & 4.31 & 4.80 & 4.02 & 4.38 & 2.17 & 4.25 & 8.09 & 3.76 \\
\hline & & $* * *$ & $* * *$ & $* *$ & $* * *$ & $* *$ & $* * *$ & & $* * *$ & & $* * *$ & & $* * *$ & & $* *$ \\
\hline
\end{tabular}


Table 3. (continued)

\begin{tabular}{|c|c|c|c|c|c|c|c|c|c|c|c|c|c|c|c|}
\hline & \multirow{2}{*}{$\begin{array}{r}\text { Maize emergence } \\
\text { Price }(€ / \mathbf{d t})\end{array}$} & \multicolumn{2}{|c|}{$\mathbf{T}=\mathbf{3 0}$} & \multicolumn{2}{|c|}{$\mathbf{T}=\mathbf{1 0}$} & \multicolumn{2}{|c|}{$T=-10$} & \multicolumn{2}{|c|}{$\mathbf{T}=\mathbf{- 3 0}$} & \multicolumn{2}{|c|}{$\mathbf{T}=\mathbf{- 5 0}$} & \multicolumn{2}{|c|}{$T=-70$} & \multicolumn{2}{|c|}{$T=-90$} \\
\hline & & 2.80 & 3.80 & 2.80 & 3.80 & 2.80 & 3.80 & 2.80 & 3.80 & 2.80 & 3.80 & 2.80 & 3.80 & 2.80 & $\mathbf{3 . 8 0}$ \\
\hline$\stackrel{\text { g }}{\mathcal{E}}$ & Weed management & 0.34 & 0.34 & 0.34 & 0.34 & 0.34 & 0.33 & 0.33 & 0.33 & 0.31 & 0.33 & 0.27 & 0.33 & 0.27 & 0.31 \\
\hline$\ddot{\ddot{m}}$ & labour demand & *** & $* * *$ & $* * *$ & $* * *$ & $* * *$ & $* * *$ & $* * *$ & $* * *$ & $* * *$ & $* * *$ & $* * *$ & $* * *$ & $* * *$ & $* * *$ \\
\hline $\begin{array}{l}\underset{\Psi}{\mathbb{E}} \\
\ddot{\mathbb{I}}\end{array}$ & Gross margin per ha & -1.12 & -1.99 & -1.11 & -1.87 & -1.09 & -1.83 & -0.87 & -1.68 & -0.94 & -1.58 & -0.73 & -1.51 & -0.37 & -1.28 \\
\hline 8 & Yield difference (model & -0.7 & -0.4 & -0.7 & -0.4 & -0.7 & -0.4 & -0.9 & -0.4 & -0.8 & -0.4 & -0.8 & -0.4 & -0.2 & -0.4 \\
\hline$\ddot{\ddot{g}}$ & yield minus real yield) & $* * *$ & $* *$ & $* *$ & & $*$ & & $* *$ & & & & & & & \\
\hline
\end{tabular}

Notes: $* * *$ and $* * *$ represent $5 \%, 1 \%$ and $0.1 \%$ significance levels using a t-test. No mark means that no significant difference occurred. Note that for tests on hypothesis H1, a Bonferroni correction was used.

We also tested the hypotheses using a Wilcoxon-Mann-Whitney test, which led overall to similar results. Only for H5, we get more significance values for the lower levels of $T$ and also higher levels of significance.

$T=$ growing degree days, which is the sum of the average temperature of each day. $\mathrm{T}=30$ : maize emerges early compared to weeds. $\mathrm{T}=-90$ : maize emerges lately compared to weeds.

Hypotheses: H1: average post-sowing strategies change in case of a glyphosate ban (average of $t_{1}$ and $t_{2}$ ),

$\mathrm{H} 2$ : costs for weed management increase in case of a glyphosate ban (average of $t_{1}$ and $t_{2}$ ),

H3: working force demand increases in case of a glyphosate ban (average of $t_{1}$ and $t_{2}$ ),

$\mathrm{H} 4$ : the gross margin decreases in case of a glyphosate ban (average of $t_{1}$ and $t_{2}$ ),

H5: yields decrease in case of a glyphosate ban (average of $t_{l}$ and $t_{2}$ ). 

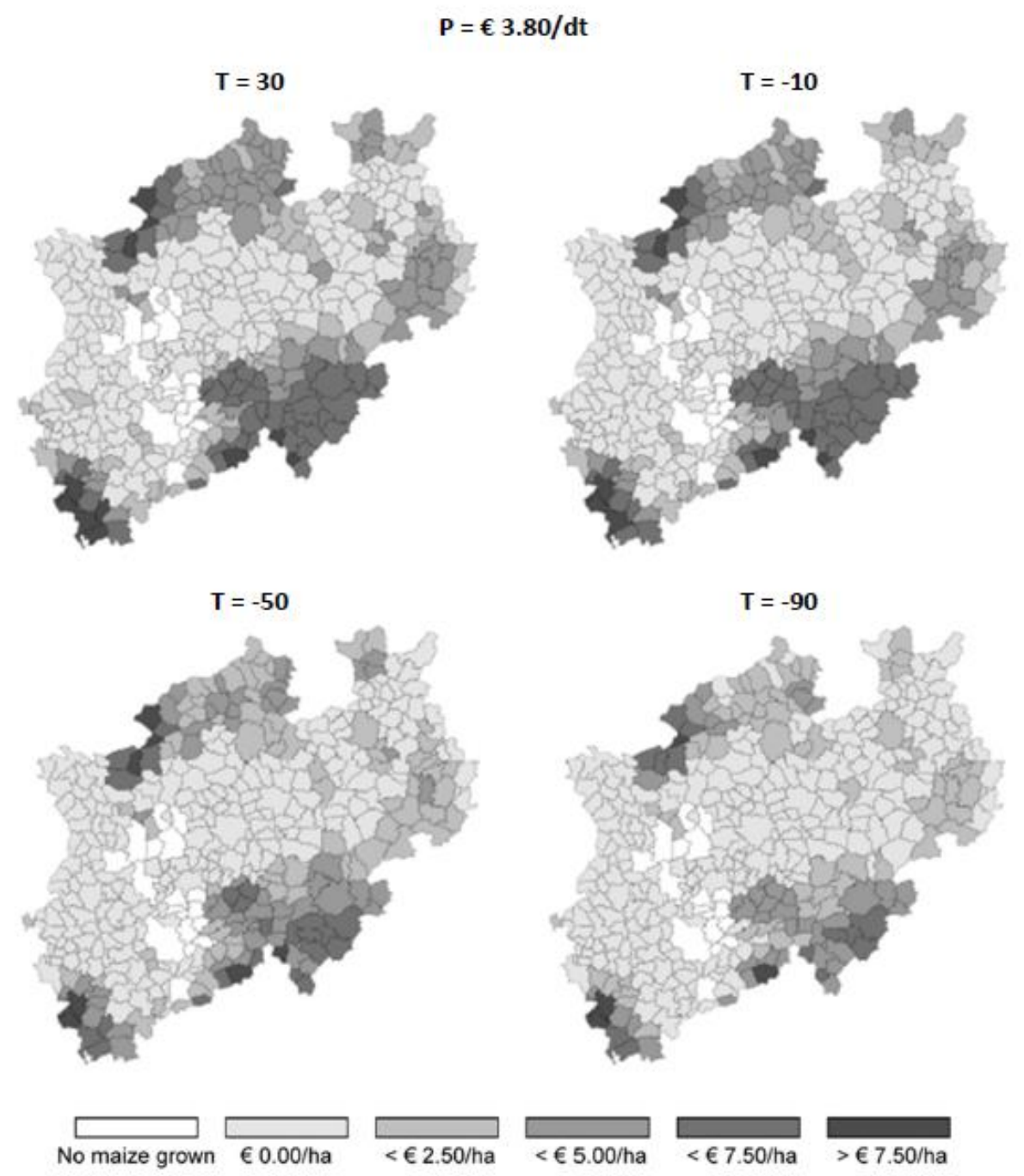

Fig. 7. Distribution of the simulated gross margin losses due to a glyphosate ban in NRW, Germany, over a two year maize growing period (for selected levels of $T$ and a price of $\mathrm{P}=€ 3.80 / \mathrm{dt}$ ).

\section{Discussion}

Our model focusses on potential changes in weed management within a single crop. Thus, our results present potential rather short-term effects in herbicide demand for weed control in silage maize production and thus can be used to quantify intensive margin effects of agrienvironmental policies targeting single herbicides. Our normative model simulates limited yield losses with some extra costs for farmers under a glyphosate ban, matching the relatively low yield increasing effect of glyphosate reported in literature (Gehring et al., 2012). In our model, this leads to a relatively high efficiency and widespread use of alternative (i.e. non- 
glyphosate based) conservation tillage strategies already under the benchmark. Under a glyphosate ban and profit maximising behaviour, overall control intensity and thus the expected maize yield would be somewhat reduced as maintaining the same level of weed suppression and the expected yield is too costly given the available alternative control strategies.

Especially due to the subsidy induced boom in biogas production from silage maize in Germany (Gömann et al., 2011; LWK NRW, 2016), silage maize is currently in shortage, being regionally traded at relatively high prices in years with moderate yields. Reducing yields under a glyphosate ban would most probably drive prices further up, such that more costly weed control strategies could become profitable. Farmers might anticipate these impacts and intensify weed control beyond the current profit optimal point to avoid acting as buyers in the short maize markets. If we restrict the model such that a certain yield has to be achieved (a safety threshold to avoid large maize purchases), also more intensive plant protection intensities are used (with costs $>€ 120 /$ ha) (not shown).

Compared to other studies being based on expert interviews (Kehlenbeck et al., 2015; Schulte et al., 2016), our results suggest lower additional costs for maize production; though at an overall lower intensity of herbicide use, which decreases somewhat the yields and thus the gross margin. However, our results are in line with findings of Schmitz and Garvert (2012), who estimated also quite limited economic losses due to a glyphosate ban for different crops for northwest Germany of up to $3 \%$ of the respective gross margins. In addition, Kehlenbeck et al. (2015) estimated that a 75\% increase of the glyphosate price would be necessary to reach equivalence of cost between pure mechanical weed management by tillage and weed management including glyphosate use. Even a higher price increase would be necessary in our model to reach equivalence of costs, but alternative mechanical strategies have to be considered as well. A sensitivity analysis with our model shows already under a $10 \%$ price increase some reductions in glyphosate use while, under a $30 \%$ increase, glyphosate was substituted by mechanical strategies in every municipality (for $\mathrm{T}=-20$ and $\mathrm{P}=€ 3.80 / \mathrm{dt}$ ). We presume that these differences to Kehlenbeck et al. (2015) reflect more detail in weed control in our model, which additionally considers adjusting 
yields. More elastic demand for herbicides as found in our analysis is also confirmed by a recent literature review (Böcker and Finger, 2017).

The observed treatment frequency in German maize production, which measures the number of herbicide applications on a field, varied between 1.31-1.47 in 2011-2015, including pre-emergence treatments with glyphosate (JKI, 2016). Our model simulated lower average treatment frequencies over the two years, which are, for instance between $0.57-1.15$ at a level of $T=0$ and between $0.95-1.21$ at $T=-50$. Indeed, pesticide intensities beyond the profit maximising intensity were also found by other authors (Jacquet et al., 2011, for France; Skevas et al., 2014, for the Netherlands) which could be explained by the risk-reducing effect of herbicides (Skevas et al., 2014). This is not reflected in the profit maximising approach used in this paper, but should be addressed in future research (e.g. Lehmann et al., 2013).

Despite the fact that regional differences in yields and weed pressure prevent an upscaling of our results to silage maize production in Germany at large, some comparison can be made. For example, the JKI also reports the average share of the surveyed German farms which use a specific AS in maize production (JKI, 2016). For example in 2015, 33\% of all surveyed farms used an herbicide strategy containing glyphosate, $91 \%$ used a strategy containing terbuthylazine, $50 \%$ used a strategy containing bromoxynil, etc. Our simulated shares over different levels of $T$ differ partly from those values. For example, bromoxynil was not selected at all, but these differences could also root in our regional focus. Still, for selected AS, and depending on $T$ and $P$, quite similar shares were calculated, e.g. for nicosulfuron, mesotrione, pethoxamid and partly for glyphosate, terbuthylazine, flufenacet, foramsulfuron and iodosulfuron. The survey of Wiese et al. (2017) finds with $22 \%$ of the farmers applying glyphosate in 2013/14 a similar value compared to our simulated ones.

Herbicide strategies considered in our model were aggregated to some extent, for instance by defining a two-time post-sowing herbicide-application-strategy as one. Future approaches could further refine the strategies such as depicting each single application according to its characteristics and time of application. This would, however, require improved data availability such as research on weed specific impacts on yields. Additional data could also allow including more generally the control impact depending on doses of 
specific pesticides in the model. So far, reduced doses are only considered in some strategies which use doses below the manufacturers' recommendation. Also, we decided to neglect potential dynamic control impacts, for instance that a conservation tillage strategy might lead to higher weed abundance in the long-term (Ball, 1992; Buhler, 1992; Schwarz and Pallutt, 2014) ${ }^{9}$ or that effective control might depress future weed infestation (Pandey, 1989; Swinton and King, 1994), as it is hard to properly account for external weed seed import in a single plot. Here, Hanzlik and Gerowitt (2011) but also Lundkvist et al. (2008) find that geographical position and soil conditions have a higher influence on weed species composition compared to previous weed management.

Future research could apply the presented approach to other field crops and implement it into a whole farm context. Other aspects to be covered in future extensions are effects of fertilisation, of preceding or catch crops and of weed control measures in autumn.

\section{Conclusions}

We develop a highly detailed, spatially explicit bio-economic model for weed control in silage maize production drawing on an output damage control approach. Here, the raster data of NetPhyD and BfN (2013) on weed occurrence are a key input to analyse weed spread in Germany. Combining this data with expert information on current weed control strategies and comprehensive yield observation data allows us to develop and parameterise our model for mechanical and herbicide based weed control use in silage maize production for 377 municipalities in the state of North-Rhine-Westphalia. Glyphosate as a non-selective herbicide is simulated in about 5 to $25 \%$ of the cases as the profit maximal strategy which combines relatively low control cost with high yields. Simulating optimal control strategies under a glyphosate ban, we find that i) economic losses of a ban are limited for farmers currently applying glyphosate, ii) costs slightly increase under a glyphosate ban as mechanical strategies for conservation tillage are used pre-sowing and accepting some yield loss, while switches to more expensive selective herbicides in post-sowing strategies are

\footnotetext{
${ }^{9}$ Using a chisel plough instead of a mouldboard plough led in field trials to an increase in soil's weed seed bank. Here, a ban of glyphosate could lead to an increase in weed seed banks in the long-term and make more intense pre- and post-sowing strategies necessary.
} 
simulated only in few cases. Therefore, potential risks linked to increased selective herbicide use are for now limited. iii) Rather, somewhat lower yields reflecting decreased weed control intensity turn out as profitable, which, however, could lead to higher regional maize prices. Finally, iv) demand of labour increases due to higher shares of mechanical strategies.

\section{Acknowledgements}

We thank the plant protection consultants of the Chamber of Agriculture of NRW and of the Chamber of Agriculture of Lower Saxony for providing valuable information supporting this research. Moreover, we thank two anonymous reviewers for constructive feedbacks on earlier versions of this paper.

\section{References}

Achilles, W., Eurich-Menden, B., Eckel, H., Frisch, J., Fritzsche, S., Fröba, N., Funk, M., Gaio, C., Grebe, S., Grimm, E., Grube, J., Hartmann, W., Horlacher, D., Kloepfer, F., Meyer, B., Sauer, N., Schroers, J. O., Schultheiß, U. and Wulf, S. (2016). Betriebsplanung Landwirtschaft 2016/17 - KTBL-Datensammlung. 25th ed. Darmstadt: Kuratorium für Technik und Bauwesen in der Landwirtschaft e.V. (KTBL).

Babcock, B. A., Lichtenberg, E. and Zilberman, D. (1992). Impact of Damage Control and Quality of Output: Estimating Pest Control Effectiveness. American Journal of Agricultural Economics 74: 163-172.

Ball, D. A. (1992). Weed Seedbank Response to Tillage, Herbicides, and Crop Rotation Sequence. Weed Science 40: 654-659.

Böcker, T. and Finger, R. (2016). European Pesticide Tax Schemes in Comparison: An Analysis of Experiences and Developments. Sustainability 8: 378/1-22.

Böcker, T. G. and Finger, R. (2017). A Meta-Analysis on the Elasticity of Demand for Pesticides. Journal of Agricultural Economics 68: 518-533.

Bosnić, A. Č. and Swanton, C. J. (1997). Economic decision rules for postemergence herbicide control of barnyardgrass (Echinochloa crus-galli) in corn (Zea mays). Weed Science 45: 557563.

Buhler, D. D. (1992). Population Dynamics and Control of Annual Weeds in Corn (Zea mays) as Influenced by Tillage Systems. Weed Science 40: 241-248.

Carrasco-Tauber, C. and Moffitt, L. J. (1992). Damage Control Econometrics: Functional Specification and Pesticide Productivity. American Journal of Agricultural Economics 74: 158162. 
Cousens, R. (1985). A simple model relating yield loss to weed density. Annals of Applied Biology 107: 239-252.

Cousens, R., Brain, P., O’Donovan, J. T. and O'Sullivan, A. (1987). The use of biologically realistic equations to describe the effects of weed density and relative time of emergence on crop yield. Weed Science 35: 720-725.

Deen, W., Weersink, A. and Turvey, C. G., Weaver, S. (1993). Weed control decision rules under uncertainty. Review of Agricultural Economics 15: 39-50.

De Mol, F., von Redwitz, C. and Gerowitt, B. (2015). Weed species composition of maize fields in Germany is influenced by site and crop sequence. Weed Research 55: 574-585.

Falconer, K. E. (1998). Managing diffuse environmental contamination from agricultural pesticides: An economic perspective on issues and policy options, with particular reference to Europe. Agriculture, Ecosystems \& Environment 69: 37-54.

Femenia, F. and Letort, E. (2016). How to significantly reduce pesticide use: An empirical evaluation of the impacts of pesticide taxation associated with a change in cropping practice. Ecological Economics 125: 27-37.

Finger, R., Möhring, N., Dalhaus, T. and Böcker, T. (2017). Revisiting pesticide taxation schemes. Ecological Economics 134: 263-266.

Fox, G. and Weersink, A. (1995). Damage Control and Increasing Returns. American Journal of Agricultural Economics 77: 33-39.

Gehring, K., Thyssen, S. and Festner, T. (2012). Effects of glyphosate application on succeeding crops. In Nordmeyer, H., Ulber, L. (eds), Proceedings 25th German Conference on Weed Biology and Weed Control, March 13-15 2012, Braunschweig, Germany. Quedlinburg: JuliusKühn-Archiv, 419-426.

Gömann, H., Kreins, P., Münch, J. and Delzeit, R. (2011). Auswirkungen der Novellierung des Erneuerbare-Energien-Gesetzes auf die Landwirtschaft in Deutschland. In Schriften der Gesellschaft für Wirtschafts- und Sozialwissenschaften des Landbaus e.V. (ed.), Möglichkeiten und Grenzen der wissenschaftlichen Politikanalyse. Münster: Landwirtschaftsverlag, 189-201.

Gross, M. (2013). EU ban puts spotlight on complex effects of neonicotinoids. Current Biology 23: R462-R464.

Grovermann, C., Schreinemachers, P., Riwthong, S. and Berger, T. (2017). „Smart‘ policies to reduce pesticide use and avoid income trade-offs: An agent-based model applied to Thai agriculture. Ecological Economics 132: 91-103.

Guan, Z., Oude Lansink, A., Wossink, A. and Huirne, R. (2005). Damage control inputs: a comparison of conventional and organic farming systems. European Review of Agricultural Economics 32: 167-189.

Guan, Z., Oude Lansink, A., van Ittersum, M. and Wossink, A. (2006). Integrating Agronomic Principles into Production Function Specification: A Dichotomy of Growth Inputs and Facilitating Inputs. American Journal of Agricultural Economics 88: 203-214. 
Guyton, K. Z., Loomis, D., Grosse, Y., El Ghissassi, F., Benbrahim-Tallaa, L., Guha, N., Scoccianti, C., Mattock, H. and Straif, K. (2015). Carcinogenicity of tetrachlorvinphos, parathion, malathion, diazinon, and glyphosate. The Lancet-Oncology 16: 490-491.

Hall, D. C. and Norgaard, R. B. (1973). On the Timing and Application of Pesticides. American Journal of Agricultural Economics 55: 198-201.

Hanzlik, K. and Gerowitt, B. (2011). The importance of climate, site and management on weed vegetation in oilseed rape in Germany. Agriculture, Ecosystems \& Environment 141: 323-331.

Hoffmann, M. (1990). Mechanische und thermische Unkrautbekämpfung. In Diercks, R., Heitefuss, R. (eds), Integrierter Landbau - Systeme umweltbewußter Pflanzenproduktion - Grundlagen . Praxiserfahrungen - Entwicklungen. München: BLV Verlagsgesellschaft, 171-182.

HRAC - Herbicide Resistance Action Committee (2005). Classification of Herbicides According to Site of Action. Online: http://hracglobal.com/tools/classification-lookup [09 November 2016].

IT NRW - Information und Technik Nordrhein-Westfalen (2016). Erntestatistik. Online: https://www.landesdatenbank.nrw.de/ldbnrw/online/ [10 November 2016].

Jacquet, F., Butault, J.-P. and Guichard, L. (2011). An economic analysis of the possibility of reducing pesticides in French field crops. Ecological Economics 70: 1638-1648.

JKI - Julius Kühn-Institut (2016). Statistische Erhebungen zur Anwendung von Pflanzenschutzmitteln in der Praxis. Online: http://papa.jki.bund.de/ [09 November 2016].

Karagiannis, G. and Tzouvelekas, V. (2012). The damage-control effect of pesticides on total factor productivity growth. European Review of Agricultural Economics 39: 417-437.

Kehlenbeck, H., Saltzmann, J., Schwarz, J., Zwerger, P., Nordmeyer, H. Roßberg, D., Karpinski, I., Strassemeyer, J., Golla, B. and Freier, B. (2015). Impact assessment of partial or complete abandonment of glyphosate application for farmers in Germany. Julius-Kühn-Archiv Nr. 451. Quedlinburg: Julius Kühn-Institut.

Kropff, M.J., Weaver, S.E. and Smits, M.A. (1992). Use of Ecophysiological Models for Crop-Weed Interference: Relations Amongst Weed Density, Relative Time of Weed Emergence, Relative Leaf Area, and Yield Loss. Weed Science 40: 296-301.

Kuosmanen, T., Pemsl, D. and Wesseler, J. (2006). Specification and Estimation of Production Functions Involving Damage Control Inputs: A Two-Stage, Semiparametric Approach. American Journal of Agricultural Economics 88: 499-511.

Lefebvre, M., Langrell, S. R. H. and Gomez-y-Paloma, S. (2015). Incentives and policies for integrated pest management in Europe: a review. Agronomy for Sustainable Development 35: $27-45$.

Lehmann, N., Briner, S. and Finger, R. (2013). The impact of climate and price risks on agricultural land use and crop management decisions. Land Use Policy 35: 119-130.

LfL - Bayerische Landesanstalt für Landwirtschaft (2016). Unkrautmanagement in Mais. Online: https://www.lf1.bayern.de/ips/unkraut/033928/index.php [09 November 2016]. 
Lichtenberg, E. and Zilberman, D. (1986). The Econometrics of Damage Control: Why Specification Matters. American Journal of Agricultural Economics 68: 261-273.

Lundkvist, A., Salomonsson, L., Karlsson, L. and Dock Gustavsson, A.-M. (2008). Effects of organic farming on weed flora composition in a long term perspective. European Journal Agronomy 28: $570-578$.

LWK NRW - Landwirtschaftskammer Nordrhein-Westfalen (2015a). Unkraut im Mais: Zweimal spritzen, Gewässer schützen. Online: http://www.landwirtsch aftskammer.de/landwirtschaft/pflanzenschutz/ackerbau/mais/spritzfolgen.htm [09 November 2016].

LWK NRW - Landwirtschaftskammer Nordrhein-Westfalen (2015b). Düngung. Online: http://www.landwirtschaftskammer.de/Landwirtschaft/ackerbau/duengung/index.htm $\quad[07$ November 2016).

LWK NRW - Landwirtschaftskammer Nordrhein-Westfalen (2016). Biogas in NordrheinWestfalen. Online: https://www.landwirtschaftskammer.de/land wirtschaft/technik/biogas/veroeffentlichungen/biogas-in-nrw.htm [14 December 2016].

Mehrtens, J., Schulte, M. and Hurle, K. (2005). Unkrautflora in Mais - Ergebnisse eines Monitorings in Deutschland. Gesunde Pflanzen 57: 206-218.

Meinlschmidt, E., Schröder, G., Bär, H., Pittorf, I. and Bergmann, E. (2008). Unkrautbekämpfung in Mais. In Sächsische Landesanstalt für Landwirtschaft (ed.), Schriftenreihe der Sächsischen Landesanstalt für Landwirtschaft. 1/2008. Dresden: Sächsische Landesanstalt für Landwirtschaft.

NetPhyD and BfN (eds) (2013). Verbreitungsatlas der Farn- und Blütenpflanzen Deutschlands. Bonn: Netzwerk Phytodiversität Deutschlands e.V. (NetPhyD) and Bundesamt für Naturschutz $(\mathrm{BfN})$.

Oerke, E.-C. (2006). Crop losses to pests. Journal of Agricultural Sciences 144: 31-43.

Oude Lansink, A. and Carpentier, A. (2001). Damage Control Productivity: An Input Damage Abatement Approach. Journal of Agricultural Economics 52: 11-22.

Oskam, A. J. (1997). The economics of pesticides: an overview of the issues. In Oskam, A. J., Vijftigschild, R. A. N. (eds), Proceedings and discussions - policy measures to control environmental impacts from agriculture - workshop on pesticides, August 1995. Wageningen Agricultural University: Wageningen, 360-384.

Pandey, S. (1989). Economics of wild oats control: an application of stochastic dynamic programming model. Paper presented to the Thirty-Third Annual Conference of the Australian Agricultural Economics Society, February 7-9, 1989, Canterbury, New Zealand.

Pannell, D. J. (1990). An economic response model of herbicide application for weed control. Australian Journal of Agricultural Economics 34: 223-241.

Roth Agrarhandel (2015). Pflanzenschutz Preisliste 2015. Online: http://www.rothagrar.de/produkte_1/pflanzenschutz/preislisten/pflanzenschutz-preisliste_2015_1.html November 2016]. 
Schmitz, P. M. and Garvert, H. (2012). Agro-Economic Analysis of the Use of Glyphosate in Germany. Journal für Kulturpflanzen 64: 150-162.

Schulte, M. and Theuvsen, L. (2015). The economic benefit of herbicides in arable farming - with a special focus on glyphosate. Journal für Kulturpflanzen 67: 269-279.

Schulte, M. C., Theuvsen, L., Wiese, A. and Steinmann, H.-H. (2016). Die ökonomische Bewertung von Glyphosat im deutschen Ackerbau. In Schriften der Gesellschaft für Wirtschafts- und Sozialwissenschaften des Landbaus e.V. (ed.), Agrar- und Ernährungswirtschaft: Regional vernetzt und global erfolgreich. Münster: Landwirtschaftsverlag, 29-41.

Schwarz, J. and Pallutt, B. (2014). Influence of tillage system on the weed infestation in a long-term field trial. In Nordmeyer, H., Ulber, L. (eds), Proceedings 26th German Conference on Weed Biology and Weed Control, March 11-13, 2014, Braunschweig, Germany. Quedlinburg: JuliusKühn-Archiv, 141-148.

Skevas, T., Stefanou, S. E. and Oude Lansink, A. (2014). Pesticide use, environmental spillovers and efficiency: A DEA risk-adjusted efficiency approach applied to Dutch arable farming. European Journal of Operational Research 237: 658-664.

Söchting, H.-P. and Zwerger, P. (2012). Weed competition and biomass production of maize and sorghum under different herbicide intensity level. In Nordmeyer, H., Ulber, L. (eds), Proceedings 25th German Conference on Weed Biology and Weed Control, March 13-15, 2012, Braunschweig, Germany. Quedlinburg: Julius-Kühn-Archiv, 329-335.

Steinmann, H.-H., Theuvsen, L. and Gerowitt, B. (2016). Rahmenbedingungen für eine künftige Anwendung von Glyphosat im Ackerbau. Agra-Europe 23/16, 6th June 2016: 11-14.

Swinton, S. M., Buhler, D. D., Forcella, F., Gunsolus, J. L. and King, R. P. (1994). Estimation of Crop Yield Loss Due to Interference by Multiple Weed Species. Weed Science 42: 103-109.

Swinton, S. M. and King, R. P. (1994). A Bioeconomic Model for Weed Management in Corn and Soybean. Agricultural Systems 44: 313-335.

Talpaz, H. and Borosh, I. (1974). Strategy for Pesticide Use: Frequency and Applications. American Journal of Agricultural Economics 56: 769-775.

Wiese, A., Schulte, M., Theuvsen, L. and Steinmann, H.-H. (2017). Interactions of glyphosate use with farm characteristics and cropping patterns in Central Europe. Pest Management Science: in press.

\section{Appendix}

Supplementary data to this article can be found online at http://dx.doi.org/10.1016/j.ecolecon.2017.08.027. 


\section{Appendix A:}

Weed control strategies included in the model and related parameters (amount/ha, costs, efficacy)

(Excel file, online)

\section{Appendix B:}

Average weed management costs (mechanical and chemical) and average gross margins

Table A1. Average gross margin (average of $t_{1}$ and $t_{2}$, all municipalities, also those without glyphosate use)

\begin{tabular}{|c|c|c|c|c|}
\hline $\bar{T}$ & $\begin{array}{l}\text { Gross margin } \\
\text { (glyphosate } \\
\text { licensed, } \\
P=€ \mathbf{2 . 8 0} / \mathbf{d t} \text { ) }\end{array}$ & $\begin{array}{l}\text { Gross margin } \\
\text { (glyphosate } \\
\text { banned, } \\
P=€ 2.80 / \text { dt) }\end{array}$ & $\begin{array}{l}\text { Gross margin } \\
\text { (glyphosate } \\
\text { licensed, } \\
\mathbf{P}=€ \mathbf{3 . 8 0} / \mathrm{dt} \text { ) }\end{array}$ & $\begin{array}{l}\text { Gross margin } \\
\text { (glyphosate } \\
\text { banned, } \\
P=€ \mathbf{3 . 8 0} / \mathbf{d t} \text { ) }\end{array}$ \\
\hline 40 & 630.93 & 630.76 & 1107.89 & 1106.96 \\
\hline 30 & 621.90 & 621.74 & 1095.22 & 1094.29 \\
\hline 20 & 612.03 & 611.87 & 1081.60 & 1080.70 \\
\hline 10 & 601.20 & 601.05 & 1067.09 & 1066.23 \\
\hline 0 & 589.21 & 589.07 & 1051.24 & 1050.41 \\
\hline-10 & 576.31 & 576.18 & 1033.46 & 1032.63 \\
\hline-20 & 562.43 & 562.31 & 1013.62 & 1012.83 \\
\hline-30 & 547.77 & 547.68 & 991.58 & 990.85 \\
\hline-40 & 532.02 & 531.93 & 967.40 & 966.71 \\
\hline-50 & 514.90 & 514.83 & 940.82 & 940.16 \\
\hline-60 & 496.64 & 496.58 & 912.16 & 911.57 \\
\hline-70 & 476.97 & 476.93 & 881.58 & 881.03 \\
\hline-80 & 456.14 & 456.09 & 849.23 & 848.74 \\
\hline-90 & 434.40 & 434.38 & 815.40 & 814.98 \\
\hline
\end{tabular}




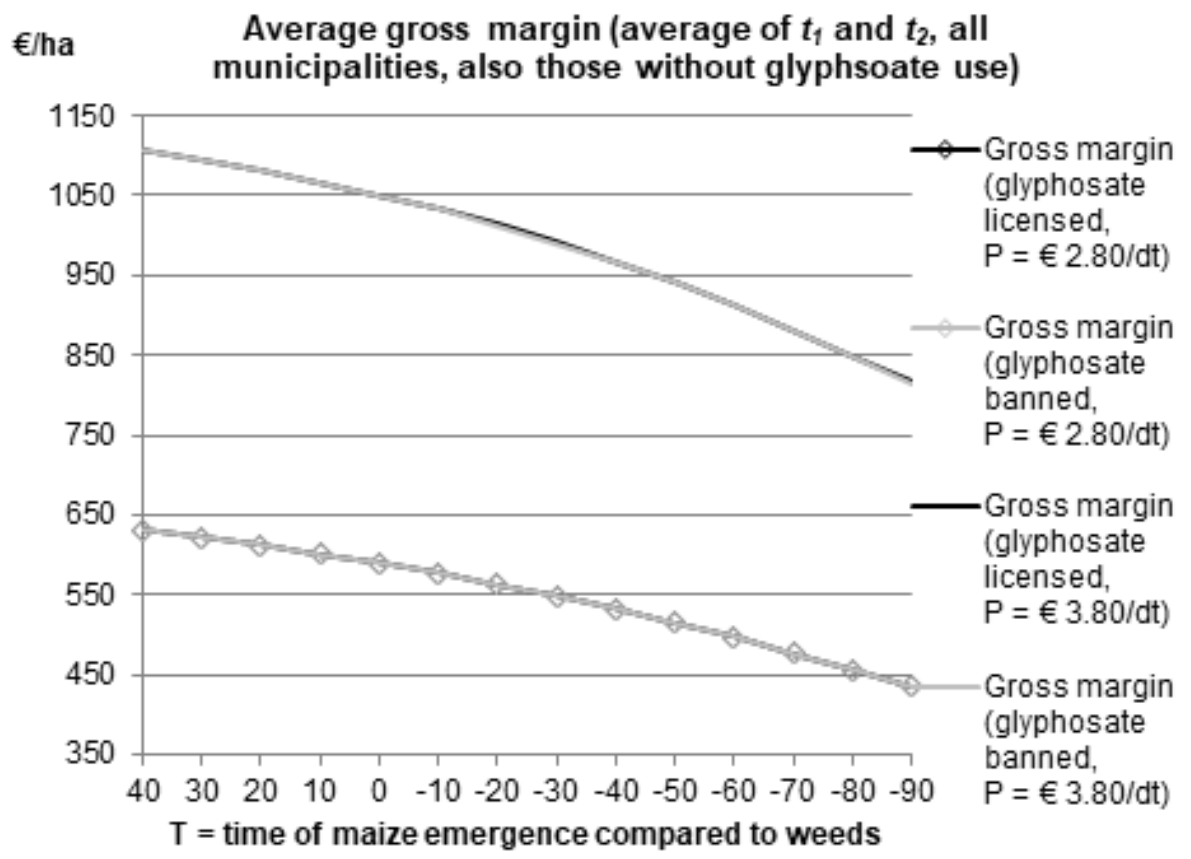

Fig. A1. Average gross margin (average of $t_{1}$ and $t_{2}$, all municipalities, also those without glyphosate use). 
Table A2. Average costs for weed management (average of $t_{1}$ and $t_{2}$, all municipalities, also those without glyphosate use $)^{\mathrm{a}}$

\begin{tabular}{|c|c|c|c|c|}
\hline $\mathbf{T}$ & $\begin{array}{l}\text { Weed } \\
\text { management } \\
\text { costs } \\
\text { (glyphosate } \\
\text { licensed, } \\
P=€ 2.80 / d t \text { ) } \\
\end{array}$ & $\begin{array}{l}\text { Weed } \\
\text { management } \\
\text { costs } \\
\text { (glyphosate } \\
\text { banned, } \\
P=€ 2.80 / \text { dt) } \\
\end{array}$ & $\begin{array}{l}\text { Weed } \\
\text { management } \\
\text { costs } \\
\text { (glyphosate } \\
\text { licensed, } \\
P=€ 3.80 / d t \text { ) } \\
\end{array}$ & $\begin{array}{l}\text { Weed } \\
\text { management } \\
\text { costs } \\
\text { (glyphosate } \\
\text { banned, } \\
P=€ 3.80 / d t \text { ) } \\
\end{array}$ \\
\hline 40 & 65.86 & 66.71 & 77.76 & 80.16 \\
\hline 30 & 68.47 & 69.35 & 82.73 & 85.29 \\
\hline 20 & 69.86 & 70.70 & 89.33 & 91.76 \\
\hline 10 & 71.59 & 72.38 & 96.27 & 98.66 \\
\hline 0 & 74.87 & 75.62 & 99.11 & 101.42 \\
\hline-10 & 80.16 & 80.88 & 100.46 & 102.66 \\
\hline-20 & 85.14 & 85.97 & 101.77 & 103.90 \\
\hline-30 & 90.19 & 90.62 & 102.58 & 104.69 \\
\hline-40 & 92.77 & 93.38 & 103.35 & 105.25 \\
\hline-50 & 94.65 & $\underline{94.96}$ & 105.41 & 107.24 \\
\hline-60 & 94.11 & 94.47 & 107.32 & 108.80 \\
\hline-70 & $\underline{94.66}$ & 94.79 & 110.20 & 111.76 \\
\hline-80 & 93.71 & 93.86 & 113.45 & 114.77 \\
\hline-90 & 93.71 & 94.08 & $\underline{115.47}$ & $\underline{116.76}$ \\
\hline
\end{tabular}

${ }^{a}$ Maximum values are underlined. 


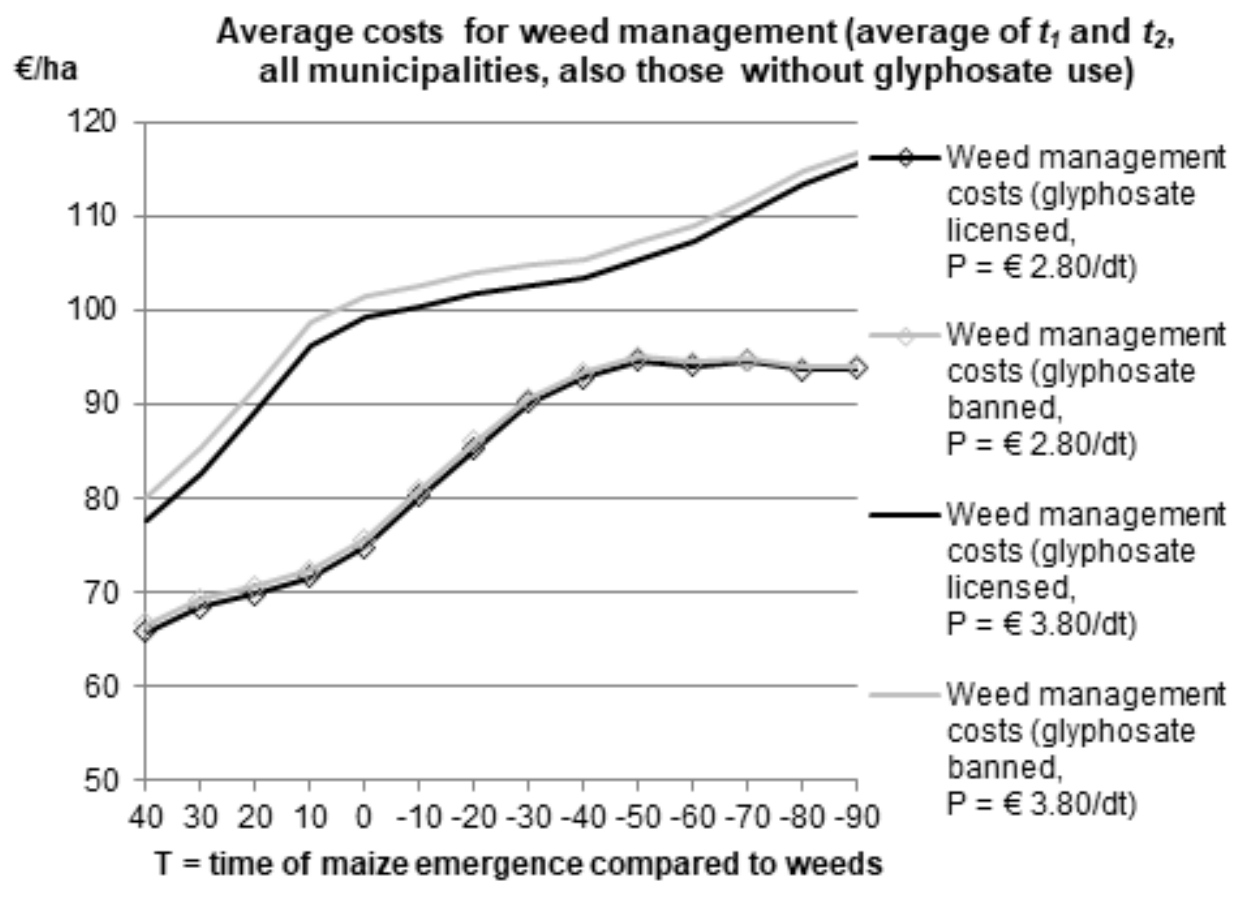

Fig. A2. Average costs for weed management (average of $t_{1}$ and $t_{2}$, all municipalities, also those without glyphosate use). 


\section{Appendix C:}

\section{Sensitivity analysis with respect to the attainable yield (the attainable yield is increased by $10 \%$ in $t_{1}$ and $15 \%$ in $t_{2}$ )}
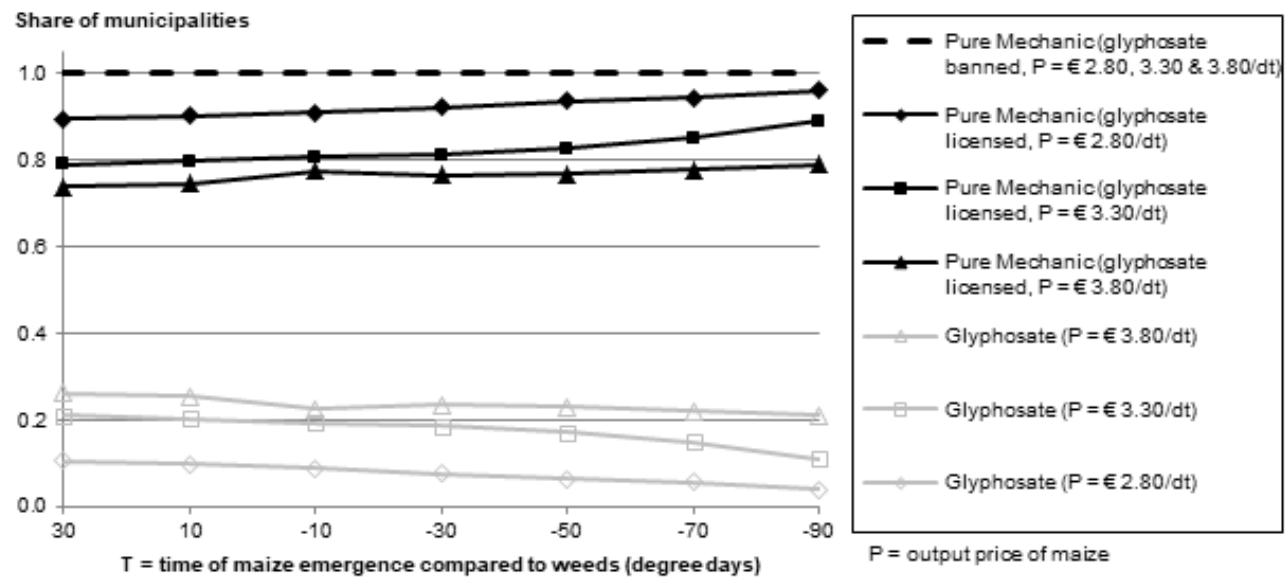

Fig. A3. Shares of used pre-sowing strategies (average of $t_{1}$ and $t_{2}$ of each municipality).

Note: A scenario in which glyphosate is licensed is compared to a scenario with a glyphosate ban. The figure shows the results for the three analysed price levels at different weed pressure levels (expressed as $T$ ).

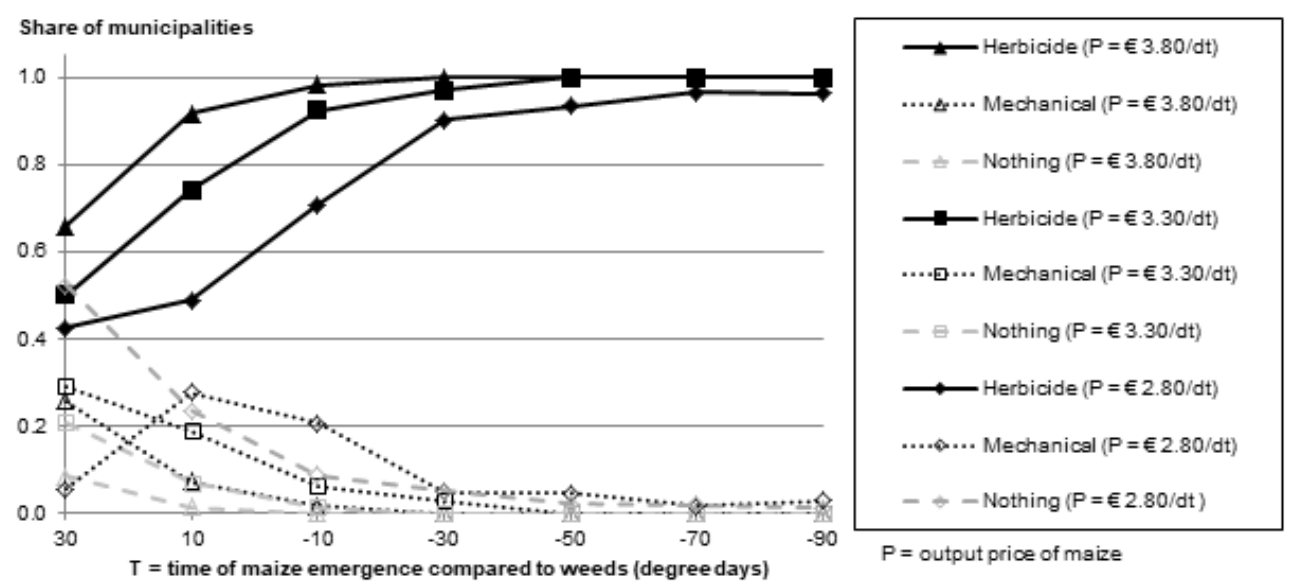

Fig. A4. Shares of post-sowing strategies as average of $t_{1}$ and $t_{2}$ (scenario with glyphosate licensed).

Note: The figure shows the categorisation of the post-sowing strategies in Herbicide, Mechanical and Nothing. Three price levels and different weed pressure levels (expressed as $T$ ) are analysed. 


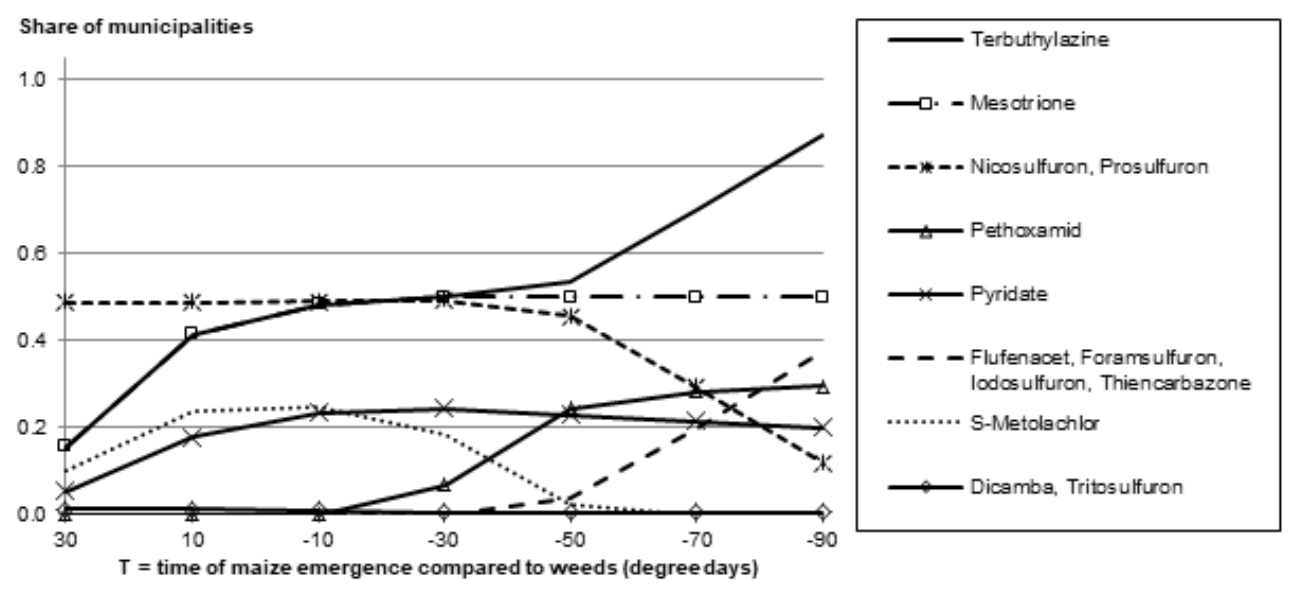

Fig. A5. Shares active substances in of post-sowing strategies (glyphosate licensed, $P=€$ $3.80 / \mathrm{dt}$, average of $t_{1}$ and $t_{2}$ ).

Note: The figure shows how often an active substance is used on average over the municipalities. For example, a level of $60 \%$ for terbuthylazine means that this substance is contained in the weed management strategy, on average of the two years, in 226 of the 377 municipalities each year. 
Table A3. Differences between glyphosate-ban-scenario and glyphosate-licensed-scenario (mean across the glyphosate using municipalities) and results of hypotheses testing

\begin{tabular}{|c|c|c|c|c|c|c|c|c|c|c|c|c|c|c|c|}
\hline & \multirow{2}{*}{$\begin{array}{r}\text { Maize emergence } \\
\text { Price }(€ / \mathbf{d t})\end{array}$} & \multicolumn{2}{|c|}{$\mathbf{T}=\mathbf{3 0}$} & \multicolumn{2}{|c|}{$\mathbf{T}=\mathbf{1 0}$} & \multicolumn{2}{|c|}{$T=-10$} & \multicolumn{2}{|c|}{$T=-30$} & \multicolumn{2}{|c|}{$T=-50$} & \multicolumn{2}{|c|}{$T=-70$} & \multicolumn{2}{|c|}{$T=-90$} \\
\hline & & 2.80 & 3.80 & 2.80 & 3.80 & 2.80 & 3.80 & 2.80 & 3.80 & 2.80 & 3.80 & 2.80 & 3.80 & 2.80 & 3.80 \\
\hline \multirow{17}{*}{ 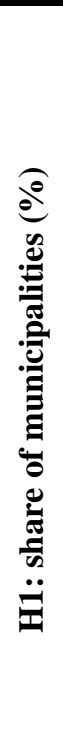 } & No Herbicide & 1.3 & - & 1.4 & $\overline{1.6}$ & 13.4 & - & 6.9 & - & 6.3 & - & - & - & - & - \\
\hline & Mechanic & - & - & - & 1.6 & - & - & 5.2 & - & 6.3 & - & - & - & -3.4 & - \\
\hline & Nothing & 1.3 & - & 1.4 & - & 13.4 & - & 1.7 & - & -6.3 & - & - & - & 3.4 & - \\
\hline & Herbicide & -1.3 & - & -1.4 & -1.6 & -13.4 & - & -6.9 & - & - & - & - & - & - & - \\
\hline & Dicamba & - & - & - & - & -4.5 & -1.2 & 1.7 & - & - & - & - & - & - & - \\
\hline & Flufenacet & - & - & - & - & - & - & - & - & - & - & - & -0.6 & - & -1.9 \\
\hline & Foramsulfuron & - & - & - & - & - & - & - & - & - & - & - & -0.6 & - & -1.9 \\
\hline & Iodosulfuron & - & - & - & - & - & - & - & - & - & - & - & -0.6 & - & -1.9 \\
\hline & Mesotrione & - & - & - & - & & 0.6 & - & -0.6 & - & -1.1 & - & - & 3.4 & 0.6 \\
\hline & Nicosulfuron & -1.3 & - & -1.4 & -1.6 & -9.0 & 0.6 & -8.6 & 0.6 & -6.2 & 1.2 & - & 0.6 & -3.4 & 1.3 \\
\hline & Pethoxamid & - & - & - & - & - & - & - & - & - & -0.6 & - & - & - & - \\
\hline & Prosulfuron & -1.3 & - & -1.4 & -1.6 & -9.0 & 0.6 & -8.6 & 0.6 & -6.2 & 1.2 & - & 0.6 & -3.4 & 1.3 \\
\hline & Pyridate & - & - & - & - & - & 0.6 & - & -0.6 & - & - & - & - & - & 0.6 \\
\hline & S-Metolachlor & - & - & - & - & - & - & - & - & - & -0.6 & - & - & 3.4 & - \\
\hline & Terbuthylazine & - & - & - & - & - & 0.6 & - & -0.6 & - & -1.1 & - & -0.6 & 3.4 & -1.3 \\
\hline & Thiencarbazone & - & - & - & - & - & - & - & - & - & - & - & -0.6 & - & -1.9 \\
\hline & Tritosulfuron & - & - & - & - & -4.5 & -1.2 & 1.7 & - & - & - & - & - & - & - \\
\hline \multirow{2}{*}{$\begin{array}{l}\underset{\Xi}{\Psi} \\
\ddot{\Xi}\end{array}$} & \multirow{2}{*}{ Weed management costs } & 4.49 & 7.01 & 4.23 & 6.62 & 5.60 & 6.36 & 5.74 & 5.72 & 6.42 & 5.10 & 4.64 & 4.65 & 0.61 & 4.09 \\
\hline & & $* *$ & $* * *$ & * & $* * *$ & $* * *$ & $* * *$ & $* * *$ & $* * *$ & $* *$ & $* * *$ & & $* * *$ & & $* * *$ \\
\hline
\end{tabular}


Table A3. (continued)

\begin{tabular}{|c|c|c|c|c|c|c|c|c|c|c|c|c|c|c|c|}
\hline & \multirow{2}{*}{$\begin{array}{r}\text { Maize emergence } \\
\text { Price }(€ / d t)\end{array}$} & \multicolumn{2}{|c|}{$\mathrm{T}=\mathbf{3 0}$} & \multicolumn{2}{|c|}{$\mathrm{T}=10$} & \multicolumn{2}{|c|}{$T=-10$} & \multicolumn{2}{|c|}{$T=-30$} & \multicolumn{2}{|c|}{$T=-50$} & \multicolumn{2}{|c|}{$T=-70$} & \multicolumn{2}{|c|}{$T=-90$} \\
\hline & & 2.80 & 3.80 & 2.80 & 3.80 & 2.80 & 3.80 & 2.80 & 3.80 & 2.80 & 3.80 & 2.80 & 3.80 & 2.80 & 3.80 \\
\hline \multirow{2}{*}{$\begin{array}{l}\stackrel{g}{\stackrel{g}{g}} \\
\ddot{\ddot{g}}\end{array}$} & Weed management & 0.33 & 0.36 & 0.32 & 0.36 & 0.33 & 0.35 & \multirow{2}{*}{$0.34 * * *$} & 0.34 & 0.35 & 0.34 & 0.32 & 0.33 & 0.26 & 0.33 \\
\hline & labour demand & $* * *$ & $* * *$ & $* * *$ & $* * *$ & $* * *$ & $* * *$ & & $* * *$ & $* * *$ & $* * *$ & $* * *$ & $* * *$ & $* * *$ & $* * *$ \\
\hline $\begin{array}{l}\stackrel{\Xi}{\Psi} \\
\ddot{\Psi} \\
\ddot{\Xi}\end{array}$ & Gross margin per ha & -1.22 & -2.13 & -1.19 & -2.12 & -1.16 & -2.08 & -1.16 & -2.00 & -1.11 & -1.85 & -0.82 & -1.68 & -0.73 & -1.51 \\
\hline के & Yield difference (model & -0.8 & -0.3 & -0.8 & -0.3 & -0.7 & -0.3 & -0.7 & -0.4 & -0.7 & -0.4 & -0.8 & -0.4 & -1.0 & -0.4 \\
\hline$\ddot{g}$ & yield minus real yield) & $* *$ & $*$ & $* *$ & & $*$ & & & & & & & & & \\
\hline
\end{tabular}

Notes: $* * *$ and $* * *$ represent $5 \%, 1 \%$ and $0.1 \%$ significance levels using a t-test. No mark means that no significant difference occurred. Note that for tests on hypothesis H1, a Bonferroni correction was used.

We also tested the hypotheses using a Wilcoxon-Mann-Whitney test, which led overall to similar results. Only for H5, we get more significance values for the lower levels of $T$ and also higher levels of significance.

$T=$ growing degree days, which is the sum of the average temperature of each day. $\mathrm{T}=30$ : maize emerges early compared to weeds. $\mathrm{T}=-90$ : maize emerges lately compared to weeds.

Hypotheses: H1: average post-sowing strategies change in case of a glyphosate ban (average of $t_{1}$ and $t_{2}$ ),

$\mathrm{H} 2$ : costs for weed management increase in case of a glyphosate ban (average of $t_{1}$ and $t_{2}$ ),

H3: working force demand increases in case of a glyphosate ban (average of $t_{1}$ and $t_{2}$ ),

$\mathrm{H} 4$ : the gross margin decreases in case of a glyphosate ban (average of $t_{1}$ and $t_{2}$ ),

H5: yields decrease in case of a glyphosate ban (average of $t_{1}$ and $t_{2}$ ). 
